\title{
Structural characterization of the $\mathrm{C} 2$ domains of classical isozymes of protein kinase $\mathrm{C}$ and novel protein kinase $\mathrm{C} \varepsilon$ by using infrared spectroscopy
}

\author{
Senena Corbalán-García, Josefa García-García, M. Susana Sánchez-Carrillo and \\ Juan C. Gómez-Fernández * \\ Departamento de Bioquímica y Biología Molecular (A), Facultad de Veterinaria, \\ Universidad de Murcia, Apartado de Correos 4021, E-30080 Murcia, Spain
}

\begin{abstract}
The amide I regions in the original infrared spectra of $\mathrm{PKC} \alpha-\mathrm{C} 2$ in the $\mathrm{Ca}^{2+}$-free and $\mathrm{Ca}^{2+}$-bound states are both consistent with a predominantly $\beta$-sheet secondary structure. Spectroscopic studies of the thermal denaturation revealed that for the PKC $\alpha$-C2 domain alone the secondary structure abruptly changed at $50^{\circ} \mathrm{C}$. While in the presence of $\mathrm{Ca}^{2+}$, the thermal stability of the protein increased considerably. Phosphatidic acid binding to the $\mathrm{PKC} \alpha-\mathrm{C} 2$ domain was characterized, and the lipid-protein binding becoming $\mathrm{Ca}^{2+}$-independent when $100 \mathrm{~mol} \%$ phosphatidic acid vesicles was used. The effect of lipid binding on secondary structure and thermal stability was also studied. In addition, the secondary structure of the $\mathrm{C} 2$ domain from the novel PKC $\varepsilon$ was also determined by IR spectroscopy and $\beta$-sheet was seen to be the major structural component. Spectroscopic studies of the thermal denaturation in $\mathrm{D}_{2} \mathrm{O}$ showed a broadening in the amide $\mathrm{I}^{\prime}$ band starting at $45^{\circ} \mathrm{C}$. Phosphatidic acid containing vesicles were used to characterize the effect of lipid binding on the secondary structure. It was observed through thermal stability experiments that the secondary structure did not change upon lipid binding and the protein stability was very high with no significant changes occurring in the secondary structure after heating.
\end{abstract}

\section{Introduction}

Protein kinase $\mathrm{C}$ (PKC) is a phospholipid-dependent serine/threonine kinase family consisting of at least eleven closely related isoenzymes. The different PKC isoenzymes play important roles in signal transduction pathways, although the exact significance of each isoenzyme is not known at present. Any elucidation of the regulation mechanism of the various PKC isoenzymes is therefore important [25].

Closer examination of protein-sequence alignments between PKC isoenzymes reveals blocks of homology between family members and, in every case, these conserved regions have been shown to define protein motifs which confer a specific localization and/or activation input on the isoenzyme [16]. The module composition allows a more precise categorization of the different PKC subfamilies. There are three main classes of PKC molecules: the classical $(\alpha, \beta \mathrm{I}, \beta \mathrm{II}, \gamma)$ that contain the conserved $\mathrm{C} 1$ and $\mathrm{C} 2$ motifs in the regulatory domain and which are activated by both $\mathrm{Ca}^{2+}$-dependent phospholipid binding and diacylglycerol; the novel $(\delta, \varepsilon, \eta, \theta, \mu)$, which also contain $\mathrm{C} 1$ and $\mathrm{C} 2$ motifs, although located in reverse order from those of the classical isoenzymes, and, which are activated by phospholipid and diacylglycerol binding in a $\mathrm{Ca}^{2+}$ independent manner; and finally, the atypical isoenzymes $(\zeta, \iota / \lambda)$, whose

\footnotetext{
${ }^{*}$ Corresponding author. Tel.: +34 968 364766; Fax: +34 968 364766; E-mail: jcgomez@um.es.
} 
regulatory domain does not contain any conserved modules and which are not activated by either $\mathrm{Ca}^{2+}$ or diacylglycerol [66].

In general, most of the proteins containing C2-domains function in signal transduction or membrane traffic [26]. Pioneer studies with the $\mathrm{C} 2 \mathrm{~A}$-domain of synaptotagmin I revealed that the $\mathrm{C} 2$ domain acts as a $\mathrm{Ca}^{2+}$ binding motif $[6,48,63]$. This function has also been demonstrated in several other $\mathrm{C} 2$-domaincontaining proteins such as classical PKCs [5,40,41,49], cPLA2 [12,43] and Nedd4 [45] all of which bind to phospholipids in a $\mathrm{Ca}^{2+}$-dependent manner. Furthermore, it has recently been found that $\mathrm{Ca}^{2+}$ forms a bridge between the $\mathrm{C} 2$ membrane-binding domain of PKC $\alpha$ and PS [42]. Moreover, there are many C2-domains that are involved in lipid binding and do not bind $\mathrm{Ca}^{2+}$, as it is the case of the $\mathrm{C} 2$ domains from the novel PKCs, the functions of which are still not well characterized $[4,11]$.

$\mathrm{X}$-ray diffraction analysis of several $\mathrm{C} 2$ domains has revealed that the structure consists of a compact $\beta$-sandwich composed of two four-stranded $\beta$-sheets $[1,11,17,36,42,44,47,48]$. Basically, three loops at the top of the domain and four at the bottom connect the eight $\beta$-strands and, interestingly, two distinct but easily interconverted topological folds have been found: topology I becomes topology II when its $\mathrm{N}$ - and $\mathrm{C}$-termini are fused and new termini are generated by cutting the loop between strands $\beta 1$ and $\beta 2[11,26]$. The $\mathrm{C} 2$ domains of classical PKCs are classified as having a type I topology, while those of novel PKCs exhibit a type II topology [11]. The existence of two topologies is a still unsolved question and, in spite of some studies, it is not clear why $\mathrm{C} 2$ domains occur in two modes. As mentioned above, novel PKCs present a unique type of $\mathrm{C} 2$ domain and, differently to classical PKCs or phospholipases, they are able to bind to acidic phospholipids in a $\mathrm{Ca}^{2+}$-independent manner. So far, very little is known about the lipid binding mechanism of these isoforms.

In the present work, we have used FT-IR to study in solution the secondary structure of the $\mathrm{C} 2$ domain of PKC $\alpha$ during $\mathrm{Ca}^{2+}$ and lipid binding independently, and that of the $\mathrm{C} 2$ domain of $\mathrm{PKC} \varepsilon$ in the present and in the absence of phosholipid and we have carried out thermal denaturation studies. Infrared spectra are known to report directly on the secondary structure of the protein backbone $[18,32,51]$. The technique is of particular value in structural studies of membrane or lipid-associated proteins $[8,50,59,65]$. Our results show that the secondary structure of the $\mathrm{C} 2$ domain of PKC $\alpha$ does not change with $\mathrm{Ca}^{2+}$ binding. On the contrary, binding to lipids produces significant conformational changes in the secondary structure of the $\mathrm{C} 2$ domain. The thermal denaturation studies revealed that both $\mathrm{Ca}^{2+}$ and lipid binding increase the stability of the complexes but by means of different mechanisms. In addition we have observed that the structural components of the $\mathrm{C} 2$-domain from $\mathrm{PKC} \varepsilon$ show several differences from the $\mathrm{C} 2$ domain of PKC $\alpha$ and these differences might be attributed to different structural motifs.

\section{Materials and methods}

\subsection{Construction of expression plasmids}

The DNA fragment corresponding to the $\mathrm{C} 2$ domains of $\mathrm{PKC} \alpha$ (residues 158-285) and $\mathrm{PKC} \varepsilon$ (residues 6 to 134) were amplified using PCR. The PKCs cDNA were a kind gift from Drs. Nishizuka and Ono (Kobe University, Kobe, Japan). The resulting PCR fragment were subcloned using sites of the bacterial expression vectors, pET28, in which the inserts were fused to $6 \mathrm{His}$ tag, respectively as described previously [23,24]. All constructs were confirmed by DNA sequencing.

\subsection{Expression and purification of the His-PKC-C2 and GST-PKC-C2 domains}

The pET28(+) plasmid containing the wild-type or mutant PKC $\alpha$-C2 domains and the pET28a( $(+)$ plasmid containing the $\mathrm{PKC} \varepsilon-\mathrm{C} 2$ domain were transformed into BL21(DE3) Escherichia coli cells. 
The bacterial cultures $\left(\mathrm{OD}_{600} 0.6\right)$ were induced for $5 \mathrm{~h}$ at $30^{\circ} \mathrm{C}$ with $0.5 \mathrm{mM}$ of isopropyl-1-thio- $\beta$ D-galactopyranoside (IPTG) (Boehringer Mannheim, Germany). The cells were lysed by sonication in lysis buffer $(25 \mathrm{mM}$ HEPES, $\mathrm{pH} 7.4$, and $100 \mathrm{mM} \mathrm{NaCl})$ containing protease inhibitors $(10 \mathrm{mM}$ benzamidine, $1 \mathrm{mM}$ PMSF and $10 \mu \mathrm{g} / \mathrm{ml}$ of trypsin inhibitor). The soluble fraction of the lysate was incubated with Ni-NTA Agarose (QIAGEN, Hilden, Germany) for $2 \mathrm{~h}$ at $4^{\circ} \mathrm{C}$. The $\mathrm{Ni}$ beads were washed with lysis buffer containing $20 \mathrm{mM}$ imidazole. The bound fractions were eluted with the same buffer containing 50,250 and $500 \mathrm{mM}$ imidazole. $6 \mathrm{His}$ tag was removed after thrombin cleavage and, finally, the PKC$\mathrm{C} 2$ domains were desalted and concentrated using an Ultrafree-5 centrifugal filter unit (Millipore Inc., Bedford, MA).

\subsection{Preparation of lipid vesicles}

Lipid vesicles were generated by mixing chloroform solutions of 1-palmitoyl-2-oleoyl-sn-glycero3-phosphocholine (phosphatidylcholine) (Avanti Polar Lipids, Inc., Alabaster, AL) and 1-palmitoyl-2oleoyl-sn-glycero-3-phosphate (POPA) (Avanti Polar Lipids, Inc., Alabaster, AL) at the desired proportions and dried from the organic solvent under a stream of nitrogen and then further dried under vacuum for $60 \mathrm{~min}$.

\subsection{IR spectroscopy}

Lyophilized PKC-C2 domains were dissolved in $\mathrm{H}_{2} \mathrm{O}$ or $\mathrm{D}_{2} \mathrm{O}$ at approximately 20 and $8 \mathrm{mg} / \mathrm{ml}$, respectively. The proteins were incubated overnight at $4{ }^{\circ} \mathrm{C}$ to maximize $\mathrm{H}-\mathrm{D}$ exchange when $\mathrm{D}_{2} \mathrm{O}$ was used. To study infrared amide bands of the proteins in the presence of lipids, small unilamellar vesicles in $\mathrm{D}_{2} \mathrm{O}$ or $\mathrm{H}_{2} \mathrm{O}$ buffer containing $25 \mathrm{mM}$ HEPES, $20 \mathrm{mM} \mathrm{NaCl}$ and $0.2 \mathrm{mM}$ EGTA, $\mathrm{pH}$ 7.4, were mixed in the desired proportions with the protein solution.

Infrared spectra were recorded using either a Bruker Vector 22 Fourier transform infrared spectrometer equipped with a MCT detector or a Philips PU9800 Fourier transform infrared spectrometer equipped with a deuterated triglycine sulfate detector. Samples were examined in a thermostated Specac 20710 cell (Specac, Kent, UK) equipped with $\mathrm{CaF}_{2}$ windows and $6 \mu \mathrm{m}$ spacers for samples in $\mathrm{H}_{2} \mathrm{O}$ medium or $50-\mu \mathrm{m}$ spacers for samples in $\mathrm{D}_{2} \mathrm{O}$ medium. The spectra were recorded after equilibrating the samples at $25^{\circ} \mathrm{C}$ for $20 \mathrm{~min}$ in the infrared cell. A total of 128 scans were accomplished for each spectrum with a nominal resolution of $2 \mathrm{~cm}^{-1}$ and then Fourier transformed using a triangular apodization function. A sample shuttle accessory was used to obtain the average background and sample spectra. The sample chamber of the spectrometer was continuously purged with dry air to prevent atmospheric water vapor obscuring the bands of interest. Samples were scanned between 25 and $75^{\circ} \mathrm{C}$ at $5^{\circ} \mathrm{C}$ intervals with a 5 -min delay between each scan using a circulation water bath interfaced to the spectrometer computer. Spectral subtraction was performed interactively using the Spectra-Calc program (Galactic Industries Corp., Salem, NH). The spectra were subjected to deconvolution and second-derivation using the same software. Fourier self-deconvolution was carried out using a bessel apodization function, a Lorentzian shape with a resolution enhancement parameter, $K$, of 2.6 and a full width at half-height of $20 \mathrm{~cm}^{-1}$. Both deconvolution and derivation gave the number and position, as well as an estimation of the bandwidth and intensity of the bands making up the amide I region. Thereafter, curve-fitting was performed and the heights, widths and positions of each band were optimized successively [29,31]. The fractional areas of the bands in the amide I region were calculated from the final fitted band areas. 


\section{Results and discussion}

\subsection{Structure of the C2 domain of PKCQ}

The amide I band decomposition of the native PKC $\alpha$-C2 domain in $\mathrm{D}_{2} \mathrm{O}$ and $0.2 \mathrm{mM}$ EGTA at $25^{\circ} \mathrm{C}$ is shown in Fig. 1. The number and initial position of the component bands were obtained from bandnarrowed spectra by Fourier deconvolution and derivation. The corresponding parameters, e.g. band position, percentage area, bandwidth of each spectral component and assignment, are shown in Table 1 for

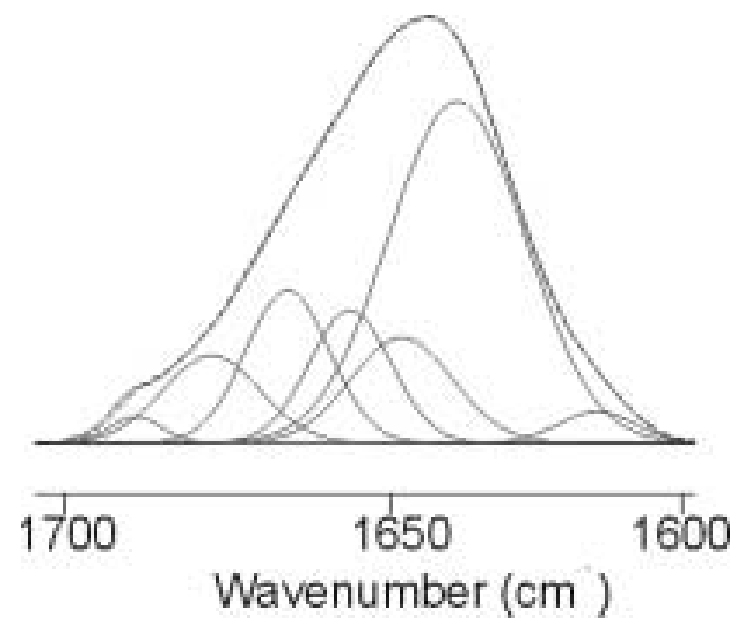

Fig. 1. FT-IR spectrum of PKC $\alpha$-C2 domain in the amide I region at $25^{\circ} \mathrm{C}$ in $\mathrm{D}_{2} \mathrm{O}$ buffer (solid line) with the fitted component bands. The position of the individual band was obtained from the resolution-enhanced spectrum. The parameters corresponding to the component bands are reflected in Table 1. Dashed line, curve fitted spectrum. Protein concentration was approximately $16 \mathrm{mg} / \mathrm{ml}$. Increment of absorbance units $(\Delta)$ were 0.05 . Reproduced with permission from Biochemistry 38 (1999), 9667-9675. Copyright 1999 Am. Chem. Soc.

Table 1

FT-IR parameters of the amide I band components of PKC-C2 domain in $\mathrm{D}_{2} \mathrm{O}$ buffer containing $25 \mathrm{mM}$ HEPES and $0.2 \mathrm{mM}$ EGTA, $2 \mathrm{mM}$ and $12.5 \mathrm{mM} \mathrm{Ca}^{2+}$, pD 7.4. Reproduced with permission from Biochemistry 38 (1999), 9667-9675. Copyright 1999 Am. Chem. Soc.

\begin{tabular}{|c|c|c|c|c|c|c|c|c|c|c|}
\hline \multirow{3}{*}{$\begin{array}{l}\text { Position }^{\mathrm{a}} \\
\left(\mathrm{cm}^{-1}\right)\end{array}$} & \multirow[t]{3}{*}{ Assignment } & \multicolumn{6}{|c|}{$25^{\circ} \mathrm{C}$} & \multirow{2}{*}{\multicolumn{3}{|c|}{$\begin{array}{c}75^{\circ} \mathrm{C} \\
0.2 \mathrm{mM} \text { EGTA }\end{array}$}} \\
\hline & & \multicolumn{2}{|c|}{$0.2 \mathrm{mM}$ EGTA } & \multicolumn{2}{|c|}{$2 \mathrm{mM} \mathrm{Ca}^{2+}$} & \multicolumn{2}{|c|}{$12.5 \mathrm{mM} \mathrm{Ca}^{2+}$} & & & \\
\hline & & $\begin{array}{l}\text { Area }^{\mathrm{b}} \\
(\%)\end{array}$ & $\begin{array}{l}\text { Width }^{\mathrm{c}} \\
\left(\mathrm{cm}^{-1}\right)\end{array}$ & $\begin{array}{l}\text { Area } \\
(\%)\end{array}$ & $\begin{array}{l}\text { Width } \\
\left(\mathrm{cm}^{-1}\right)\end{array}$ & $\begin{array}{c}\text { Area } \\
(\%)\end{array}$ & $\begin{array}{l}\text { Width } \\
\left(\mathrm{cm}^{-1}\right)\end{array}$ & $\begin{array}{l}\text { Position } \\
\left(\mathrm{cm}^{-1}\right)\end{array}$ & $\begin{array}{c}\text { Area } \\
(\%)\end{array}$ & $\begin{array}{l}\text { Width } \\
\left(\mathrm{cm}^{-1}\right)\end{array}$ \\
\hline 1688 & $\beta$-turns & 1 & 12 & 2 & 12 & 3 & 13 & 1680 & 11 & 19 \\
\hline 1675 & Antiparallel $\beta$-sheet & 9 & 22 & 8 & 21 & 7 & 17 & 1670 & 13 & 13 \\
\hline 1663 & $\beta$-turns & 14 & 19 & 14 & 19 & 16 & 18 & 1663 & 14 & 20 \\
\hline 1652 & $\begin{array}{l}\alpha \text {-helix/turns with dihedral } \\
\text { angles similar to } \alpha \text {-helix }\end{array}$ & 12 & 19 & 12 & 19 & 14 & 17 & 1647 & 34 & 28 \\
\hline 1644 & Random/ open loops & 12 & 24 & 13 & 24 & 9 & 19 & 1631 & 16 & 22 \\
\hline 1635 & $\beta$-sheet & 51 & 32 & 50 & 32 & 51 & 31 & 1615 & 23 & 19 \\
\hline
\end{tabular}

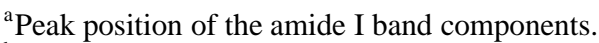

${ }^{\mathrm{b}}$ Percentage area of the band components of amide I. The areas corresponding to side-chain contributions located at $1615-$ $1600 \mathrm{~cm}^{-1}$ have not been considered.

${ }^{c}$ Half bandwidth of the amide I components. The values are rounded off to the nearest integer. 
both $\mathrm{H}_{2} \mathrm{O}$ and $\mathrm{D}_{2} \mathrm{O}$. The spectra in $\mathrm{H}_{2} \mathrm{O}$ showed six components in the amide I region. The main component accounting for $50 \%$ of the total band area was localized at $1639 \mathrm{~cm}^{-1}$ and it can be assigned to $\beta$-structure [28]. The component localized at $1657 \mathrm{~cm}^{-1}$ which contributes a $22 \%$ of the total area may be assigned to either $\alpha$-helix or disordered structure [28]. The components appearing at $1678 \mathrm{~cm}^{-1}(8 \%)$ and $1668 \mathrm{~cm}^{-1}(11 \%)$ arise from $\beta$-turns [20,21] and the component centered at $1688 \mathrm{~cm}^{-1}(11 \%)$ was assigned to antiparallel $\beta$-sheet [28]. On the other hand, the component at 1616 was supposed to be originated from the absorption of lateral chains and hence it was not taken into account for the quantification of the different types of secondary structure. In summary the secondary structure of the $\mathrm{C} 2$ domain of PKC $\alpha$ in $\mathrm{H}_{2} \mathrm{O}$ was $59 \% \beta$-pleated sheet, after adding the areas of components at 1639 and $1688 \mathrm{~cm}^{-1}$, $22 \%$ assigned to $\alpha$-helix, open loops and disordered structures and $19 \% \beta$-turns (Table 1).

The spectra in $\mathrm{D}_{2} \mathrm{O}$ exhibit seven component bands in the $1700-1600 \mathrm{~cm}^{-1}$ region and the quantitative contribution of each band to the total amide I contour, obtained by band curve-fitting of the original spectra are shown in Table 1. The major component in the amide $\mathrm{I}^{\prime}$ region appears at $1635 \mathrm{~cm}^{-1}$, and so clearly arises from intramolecular $\mathrm{C}=\mathrm{O}$ vibrations of $\beta$-sheets $[14,19,29,31,37,51]$ and corresponds to the band appearing at $1639 \mathrm{~cm}^{-1}$ in $\mathrm{H}_{2} \mathrm{O}$ buffer. The high frequency component at $1675 \mathrm{~cm}^{-1}$ can be assigned to the antiparallel $\beta$-sheet structure $[3,31]$. Although $\alpha$-helix usually absorbs at around $1652 \mathrm{~cm}^{-1}$, bands originating from turns, with dihedral angles comparable to those of $\alpha$-helix, have also been described at this frequency [21,31,51]. The band near $1644 \mathrm{~cm}^{-1}$ can be attributed to non-structured conformations, including open loops [14,18]. The bands located at $1663 \mathrm{~cm}^{-1}$ and $1688 \mathrm{~cm}^{-1}$ arise from $\beta$-turns $[3,32]$. Additionally, there is a band at about $1612 \mathrm{~cm}^{-1}$, which has been assigned to side chain absorption $[18,21,22]$, and so, its contribution is not included in the calculation of the secondary structure of PKC-C2. The secondary structure of PKC $\alpha$-C2 domain (Table 1) is $60 \% \beta$-sheet (taking into account the 1635 and $1675 \mathrm{~cm}^{-1}$ bands), $12 \% \alpha$-helix/dihedral turns (similar to $\alpha$-helix), $15 \% \beta$-turns and $12 \%$ open loops and non-structured conformation.

It is interesting to compare here the results obtained through spectra taken in the presence of $\mathrm{H}_{2} \mathrm{O}$ and $\mathrm{D}_{2} \mathrm{O}$. One of the advantages of obtaining spectra in $\mathrm{D}_{2} \mathrm{O}$ is that it is allowed to discern between the components corresponding to $\alpha$-helix and disordered structure which however appeared unresolved in $\mathrm{H}_{2} \mathrm{O}$ buffer. The data shown present a good correlation between the spectra taken in both type of solvents. They present $60 \%\left(\mathrm{D}_{2} \mathrm{O}\right)$ and $59 \%\left(\mathrm{H}_{2} \mathrm{O}\right)$ for $\beta$-sheet, $24 \%$ for the addition of $\alpha$-helix and disordered structure in $\mathrm{D}_{2} \mathrm{O}$ (adding components at 1652 and $1644 \mathrm{~cm}^{-1}$ ) versus $22 \%$ in $\mathrm{H}_{2} \mathrm{O}$ and finally $15 \%$ and $18 \%$ for $\beta$-turns in $\mathrm{D}_{2} \mathrm{O}$ and $\mathrm{H}_{2} \mathrm{O}$, respectively.

Another interesting comparison to be made is between the secondary structure composition deduced from infrared spectroscopy (this paper) and from X-ray diffraction (XRD) [42]. Table 2 shows that the agreement was strikingly good between both techniques with $\beta$-structure amounting to 60 and $57 \%$ for IR (in $\mathrm{D}_{2} \mathrm{O}$ ) and XRD respectively, $\alpha$-helix plus big loops being 125 for both techniques, $\beta$-turns amounting to 15 and $16 \%$ for IR and XRD, respectively, and disordered structure plus open loops 12 and $14 \%$ for IR and XRD, respectively.

\subsection{Effect of $\mathrm{Ca}^{2+}$-binding on the structure and stability of $C 2$ domain of $P K C \alpha$}

Although it has been demonstrated previously that the $\mathrm{PKC} \alpha-\mathrm{C} 2$ domain is involved in $\mathrm{Ca}^{2+}$ binding, it is not clear whether this binding affects the conformation of the protein. We studied the effect of $\mathrm{Ca}^{2+}$ binding on the secondary structure of the $\mathrm{PKC} \alpha-\mathrm{C} 2$ domain using 2 and $12.5 \mathrm{mM} \mathrm{CaCl}_{2}$, which, in the conditions of the assay represent $\mathrm{Ca}^{2+}$ /protein ratios of $2: 1$ and $14: 1$, respectively. Based on the binding assays performed by Nalefski et al. [12] for the C2 domain of cytosolic phospholipase A2, the higher 
Table 2

\begin{tabular}{|c|c|c|c|}
\hline & $\begin{array}{c}\text { Area } \\
(\%)\end{array}$ & $\begin{array}{l}\text { Width } \\
\left(\mathrm{cm}^{-1}\right)\end{array}$ & $\begin{array}{c}\text { Maximum } \\
\left(\mathrm{cm}^{-1}\right)\end{array}$ \\
\hline$\beta$-sheet & 50 & 32 & 1639 \\
\hline $\begin{array}{l}\alpha \text {-helix and } \\
\text { large loops and } \\
\text { random }\end{array}$ & 22 & 23 & 1657 \\
\hline$\beta$-turns & 11 & 19 & 1668 \\
\hline$\beta$-turns & 8 & 21 & 1678 \\
\hline $\begin{array}{c}\text { Antiparallel } \\
\beta \text {-sheet }\end{array}$ & 9 & 27 & 1688 \\
\hline
\end{tabular}

concentration would produce maximal binding, while $2 \mathrm{mM}$ is a non-saturating concentration under the conditions of the FT-IR experiment. The spectra of the protein at $25^{\circ} \mathrm{C}$ in the presence of 2 and $12.5 \mathrm{mM}$ $\mathrm{CaCl}_{2}$ both look very similar to that described above for the protein in the absence of $\mathrm{CaCl}_{2}$ (not shown here, see García-García et al. [24]), including the number and position of the amide I component bands. There is only a component at $1644 \mathrm{~cm}^{-1}$ which shows a significant decrease at $12.5 \mathrm{mM} \mathrm{CaCl}_{2}$ going down to $9 \%$ whereas it was $13 \%$ in the absence of $\mathrm{Ca}^{2+}$.

Further insight into the structural changes that occur during ligand binding was obtained from thermal stability studies. The deconvolved FT-IR spectra of the PKC $\alpha$-C2 domain in $\mathrm{D}_{2} \mathrm{O} /$ EGTA buffer revealed major changes in the amide I mode between 50 and $65^{\circ} \mathrm{C}$ (Fig. 2A). These changes included a broadening of the overall amide I contour and the appearance of well defined components at 1615 and $1680 \mathrm{~cm}^{-1}$, which is highly characteristic of thermally denatured proteins $[29,58]$. These components indicate that extended structures were formed by aggregation of the unfolded proteins, which were produced as a consequence of irreversible thermal denaturation [31,58]. It is also remarkable to note that apart from the appearance of the 1615 and $1680 \mathrm{~cm}^{-1}$ components, other changes in the structure resulted from protein denaturation. The spectrum corresponding to $55-75^{\circ} \mathrm{C}$ shows a $1647 \mathrm{~cm}^{-1}$ band as the major component, which corresponds to an unordered structure and represents $34 \%$ of the total area (Table 1). The band at $1631 \mathrm{~cm}^{-1}$ corresponds to a $\beta$-sheet structure and shows two main changes: the percentage of the total area has decreased to $16 \%$, and the maximum wavelength of this component has shifted from $1635 \mathrm{~cm}^{-1}$ at $25^{\circ} \mathrm{C}$ to $1631 \mathrm{~cm}^{-1}$ at $75^{\circ} \mathrm{C}$ (Fig. 2B). Thus, thermal denaturation of the PKC $\alpha$ $\mathrm{C} 2$ domain is characterized by irreversible aggregation and unfolding of the $\beta$-sheet structure into a disordered structure.

Figure 3 shows the effect of non-saturating $(2 \mathrm{mM})$ and saturating $(12.5 \mathrm{mM}) \mathrm{Ca}^{2+}$ on the thermal denaturation of the PKC $\alpha-\mathrm{C} 2$ domain. The addition of $2 \mathrm{mM} \mathrm{Ca}^{2+}$ increases the temperature at which thermal denaturation occurs from $55^{\circ} \mathrm{C}$ to $65^{\circ} \mathrm{C}$ (Fig. 3A) and the final effect was very similar to that obtained in the absence of $\mathrm{Ca}^{2+}$ (compare to Fig. 2A). However, with $12.5 \mathrm{mM} \mathrm{CaCl}_{2}$ the whole process is shifted to higher temperatures (Fig. 3B), indicating that the domain has a higher stability when bound to $\mathrm{Ca}^{2+}$. The half-midpoint temperature of thermal denaturation was calculated to be about $52-53^{\circ} \mathrm{C}$ when EGTA was used, $59-60^{\circ} \mathrm{C}$ in the presence of $2 \mathrm{mM} \mathrm{Ca}^{2+}$ and above $70^{\circ} \mathrm{C}$ in the presence of $12.5 \mathrm{mM} \mathrm{Ca}^{2+}$ [24]. 


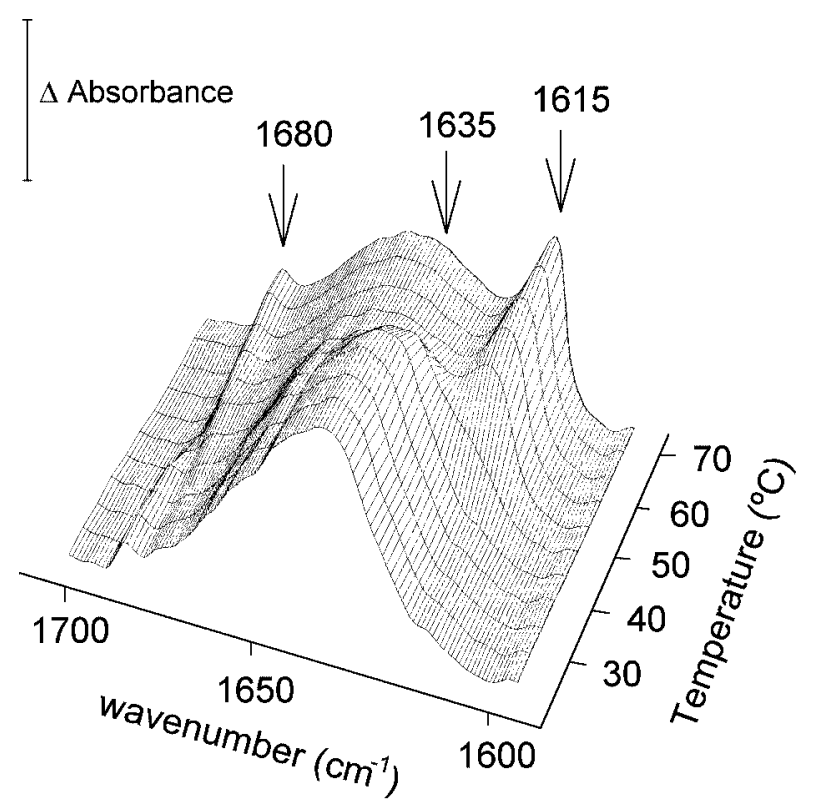

(A)

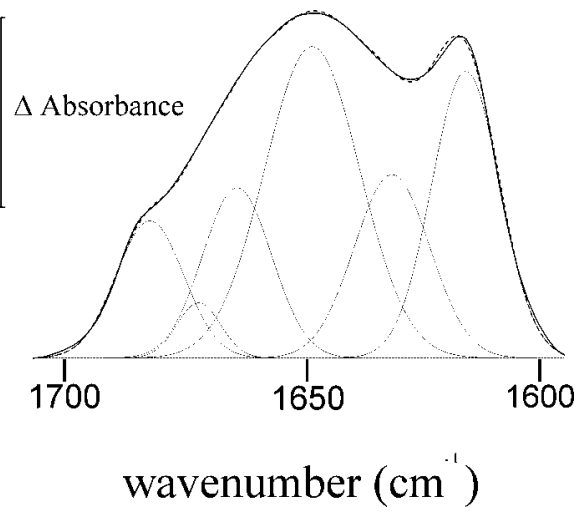

(B)

Fig. 2. (A) Deconvolved FT-IR spectrum of PKC $\square-\mathrm{C} 2$ domain in $\mathrm{D}_{2} \mathrm{O}$ buffer containing $0.2 \mathrm{mM}$ EGTA in the amide I region $\left(1700-1600 \mathrm{~cm}^{-1}\right)$ as a function of temperature from 25 to $75^{\circ} \mathrm{C}$. Fourier self-deconvolution was carried out using a Lorentzian line-shape, a bandwidth of $18 \mathrm{~cm}^{-1}$ and a resolution enhancement factor of 2.4. (B) Amide I band decomposition of thermally denatured $\mathrm{PKC} \alpha-\mathrm{C} 2$ domain at $75^{\circ} \mathrm{C}$. Increment of absorbance units $(\Delta)$ were 0.05 . The parameters corresponding to the component bands are reflected in Table 1. Reproduced with permission from Biochemistry 38 (1999), 9667-9675. Copyright 1999 Am. Chem. Soc.

A

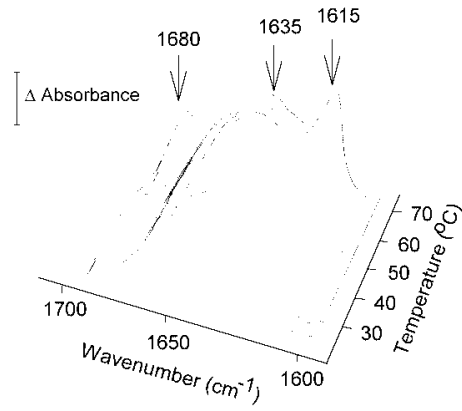

B

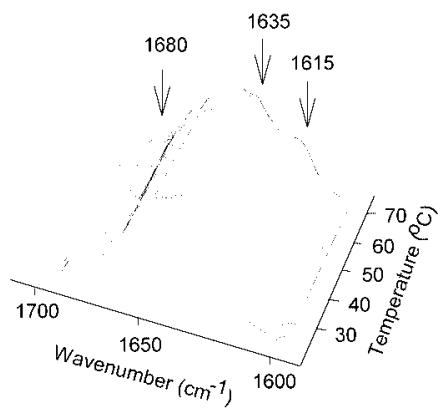

Fig. 3. Deconvolved FT-IR spectrum of PKC $\square-\mathrm{C} 2$ domain in $\mathrm{D}_{2} \mathrm{O}$ buffer containing $2 \mathrm{mM} \mathrm{Ca}^{2+}$ (A) and $12.5 \mathrm{mM} \mathrm{Ca}^{2+}(\mathrm{B})$ in the amide I region $\left(1700-1600 \mathrm{~cm}^{-1}\right)$ as a function of temperature from 25 to $75^{\circ} \mathrm{C}$. Increment of absorbance units $(\Delta)$ were 0.05. Reproduced with permission from Biochemistry 38 (1999), 9667-9675. Copyright 1999 Am. Chem. Soc.

To further demonstrate that $\mathrm{Ca}^{2+}$ is involved in conferring a higher stability against thermal denaturation to the $\mathrm{PKC} \alpha-\mathrm{C} 2$ domain, we used a construct which contains two mutations from Asp246/248 to Asn (PKC $\alpha-\mathrm{C} 2-\mathrm{D} 246 / 248 \mathrm{~N})$ and that is not able to bind $\mathrm{Ca}^{2+}$ [49]. The FT-IR spectrum at $25^{\circ} \mathrm{C}$ was very similar to that of $\mathrm{PKC} \alpha-\mathrm{C} 2$. Thermal denaturation experiments were performed under the same conditions described above for wild type protein, and it was found that when the mutant was incubated in the presence of EGTA, the denaturation pattern showed higher stability with a transition temperature 
of $64-65^{\circ} \mathrm{C}$. Maximal denaturation was reached at $70^{\circ} \mathrm{C}$, as with the wild type $\mathrm{PKC} \alpha-\mathrm{C} 2$ domain. However, when $\mathrm{Ca}^{2+}$ was added at concentrations of 2 and $12.5 \mathrm{mM} \mathrm{[24]} \mathrm{thermal} \mathrm{stability} \mathrm{was} \mathrm{unaffected,}$ and the transition temperature remained constant at $64-65^{\circ} \mathrm{C}$, suggesting that $\mathrm{Ca}^{2+}$ binding is important for stabilization, and demonstrating that $\mathrm{Ca}^{2+}$ does not stabilize the protein structure of this mutant as it does the structure of the wild type.

$\mathrm{X}$-ray studies of this $\mathrm{C} 2$ domain have shown an eight-stranded antiparallel $\beta$-sandwich involving $60 \%$ of the amino acidic residues [42]. These $\beta$-sheets are connected by several turns and three loops. Loops 1 and 3 are involved in $\mathrm{Ca}^{2+}$ binding in $\mathrm{C} 2$ domains of topology I. In particular, the crystal structure of the $\mathrm{C} 2$ domain of PKC $\alpha$ has revealed three $\mathrm{Ca}^{2+}$ binding sites [56]. All three sites appear to be hexacoordinate or heptacoordinate, with $\mathrm{Ca}^{2+}$-ligand coordination distances ranging from 2.4-2.6 $\AA$. Our FT-IR studies on the free-state $\mathrm{PKC} \alpha$-C2 domain also show antiparallel $\beta$-sheets as the major structure (Fig. 1 and Table 1). In the presence of $\mathrm{Ca}^{2+}$, no changes in the secondary structure were observed (Fig. 2 and Table 1). These data correlate well with other data previously obtained for the $\mathrm{C} 2$ domain of synaptotagmin I, where $\mathrm{Ca}^{2+}$ binding only involves rotations of some side chains but causes no substantial backbone rearrangement [63,64].

Thus, from the data obtained above, we can conclude that $\mathrm{Ca}^{2+}$ does not induce a major change in the secondary structure of the $\mathrm{C} 2$ domain of $\mathrm{PKC} \alpha$. However, it is still not clear how $\mathrm{Ca}^{2+}$ regulates the $\mathrm{C} 2$ domain function. When further information on the effect of $\mathrm{Ca}^{2+}$ on the $\mathrm{C} 2$ domain was sought using thermal denaturation studies and site-directed mutagenesis, we found that the denaturation mechanism involves irreversible aggregation and unfolding of the scaffold $\beta$-sandwich. $\mathrm{Ca}^{2+}$ binding stabilized the protein- $\mathrm{Ca}^{2+}$ complex during thermal denaturation and the half-midpoint of denaturation temperature shifted from 50 to $60^{\circ} \mathrm{C}$ at $2 \mathrm{mM} \mathrm{Ca}^{2+}$ and to approximately $70^{\circ} \mathrm{C}$ at $12.5 \mathrm{mM} \mathrm{Ca}^{2+}$ [24]. Similar results were obtained by circular dichroism for the $\mathrm{C} 2$ domain of synaptotagmin $\mathrm{I}$, where $\mathrm{Ca}^{2+}$ binding induced a shift in the denaturation temperature from $55^{\circ} \mathrm{C}$ to $74^{\circ} \mathrm{C}$ [63].

Studies performed with PKC $\alpha-C 2 D 246 / 248 \mathrm{~N}$ mutant revealed that these two mutations of Asp 246 and Asp 248 to Asn are capable of producing by themselves an increase in the domain's stability during thermal denaturation, when the transition temperature shifted from 52 to $64^{\circ} \mathrm{C}$. This temperature shift is very similar to that obtained when a non-saturating $\mathrm{Ca}^{2+}$ concentration was used. Taking into account that we only mutated two of the five residues involved in $\mathrm{Ca}^{2+}$ binding, these results indicate that neutralization of the negative charges existing in this crevice, either by $\mathrm{Ca}^{2+}$ binding or substitution of Asp residues by Asn, is an important mechanism for stabilizing the protein. Thus, these data confirm that, at least in the case of the $\mathrm{C} 2$ domain of $\mathrm{PKC} \alpha$, while $\mathrm{Ca}^{2+}$ does not induce a major conformational change, it does produce a structural stabilization that could account for $\mathrm{Ca}^{2+}$ regulation, and might modulate the interaction of the domain with acidic lipids.

\subsection{Effect of lipid binding on the PKC $\alpha$-C2 domain}

FT-IR was used to characterize the effect of $\mathrm{PKC} \alpha$-C2 domain's binding to phosphatidic acid on its secondary structure in the absence of $\mathrm{Ca}^{2+}$. It was observed [24] that the effect of the lipid on the secondary structure was significant (Table 3 ) so that the secondary structure composition for the PKC $\alpha$ $\mathrm{C} 2$ domain bound to phosphatidic acid vesicles yielded values of $47 \% \beta$-sheet, $21 \%$ random, $14 \% \alpha$ helix/dihedral turns similar to $\alpha$-helix and $17 \% \beta$-turns. It is interesting to note this effect of lipids on the secondary structure of the PKC $\alpha$-C2 domain, especially the decrease in the $\beta$-sheet component from 60 to $47 \%$ and the increase in the component assigned to random and open loops structure from 12 to $21 \%$, when comparing with protein in the absence of lipids (Table 1). 
Table 3

Comparison of the composition $(\%)$ of the secondary structure obtained from infrared spectroscopy and from X-ray diffraction of the C2-domains from $\mathrm{PKC} \alpha$ and from $\mathrm{PKC} \varepsilon$

\begin{tabular}{lccccc}
\hline Structure & \multicolumn{3}{c}{ C2-PKC $\alpha$} & & \multicolumn{2}{c}{ C2-PKC $\varepsilon$} \\
\cline { 2 - 3 } \cline { 5 - 6 } & FT-IR & X-ray diffraction & & FT-IR & X-ray diffraction \\
& $(\%)$ & $(\%)$ & & $(\%)$ & $(\%)$ \\
\hline$\beta$-sheet & 60 & 57 & & 60 & 54 \\
$\alpha$-helix and large loops & 12 & 12 & & 21 & 20 \\
$\beta$-turns & 15 & 16 & & 19 & 20 \\
Random and open loops & 12 & 14 & & \\
\hline
\end{tabular}

A

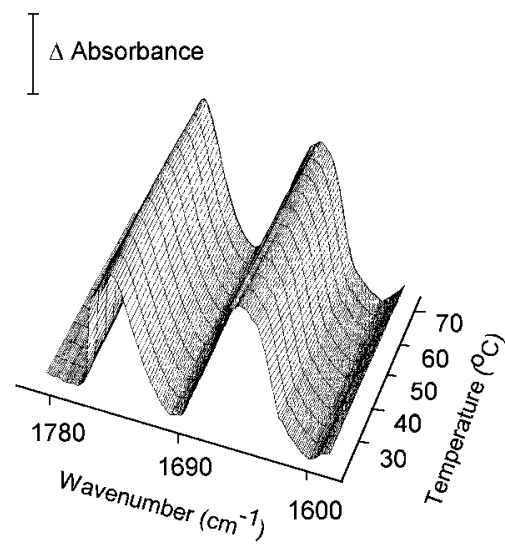

B

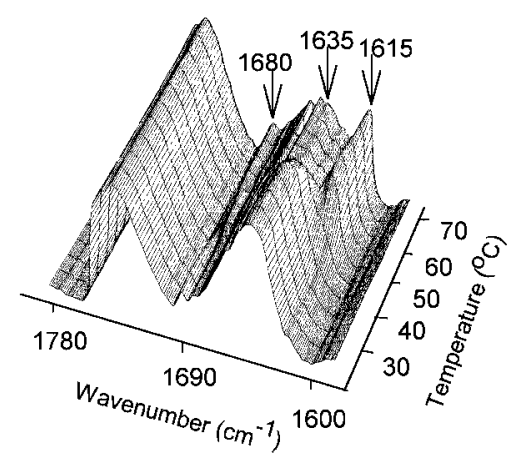

C

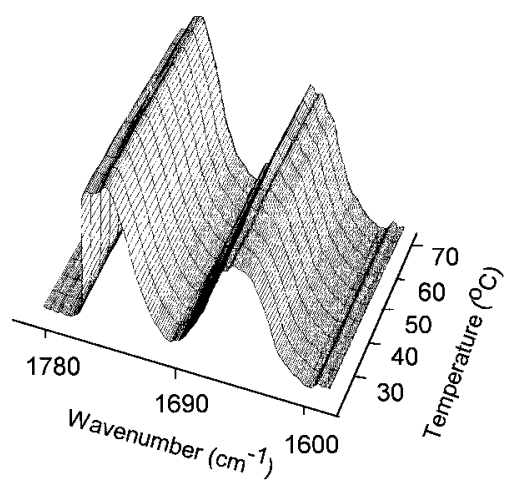

Fig. 4. Deconvolved FT-IR spectrum of PKC $\alpha$-C2 domain in the presence of lipidic vesicles in the $1800-1600 \mathrm{~cm}^{-1}$ region obtained at different temperatures. Phosphatidic acid vesicles were incubated with $\mathrm{PKC} \alpha-\mathrm{C} 2$ domain (A) phosphatidylcholine vesicles and PKC $\alpha-\mathrm{C} 2$ domain were used as control (B) and PKC $\alpha-\mathrm{C} 2 \mathrm{D} 246 / 248 \mathrm{~N}(\mathrm{C})$. Increment of absorbance units $(\Delta)$ were 0.1. Reproduced with permission from Biochemistry 38 (1999), 9667-9675. Copyright 1999 Am. Chem. Soc.

We have previously demonstrated that the mutant PKC $\alpha$-C2D246/248N binds phosphatidic acid although is not able to bind $\mathrm{Ca}^{2+}$ [24]. The percentages of components obtained after band decomposition of the amide I band of this mutant in the presence of vesicles containing $100 \mathrm{~mol} \%$ phosphatidic were also obtained, and it was interesting that the percentages of the $\beta$-sheet and unordered structure components changed as with wild type protein, which confirms the binding of the domain to lipid vesicles in these conditions in which $\mathrm{Ca}^{2+}$ was not present.

The binding site for phosphatidic acid, in the absence of $\mathrm{Ca}^{2+}$ must take place on the lysines-rich cluster located in $\beta$-strands 3 and 4 where it has recently been observed that phosphatidic acid binds. Several studies have shown that activation of classical PKCs involves conformational changes, including the removal of the pseudosubstrate region from the active site of PKC $[60,61]$. Thus, ours results suggest that the $\mathrm{C} 2$ domain might also be involved in this conformational change during lipid binding which leads to protein activation

The effect of heating on the structure of PKC $\alpha-\mathrm{C} 2$ in the presence of phosphatidic acid was also studied by FT-IR (Fig. 4). In the presence of lipid vesicles containing $100 \mathrm{~mol} \%$ phosphatidic acid, PKC $\alpha$-C2 did not change its FT-IR profile significantly in the temperature range tested, suggesting a large increase in 


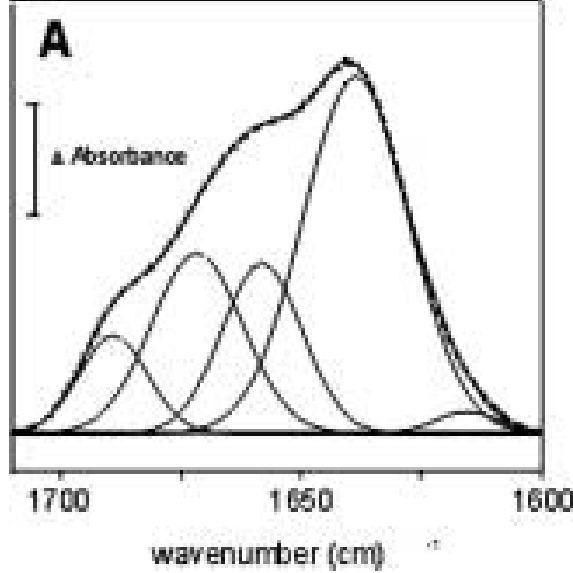

(A)

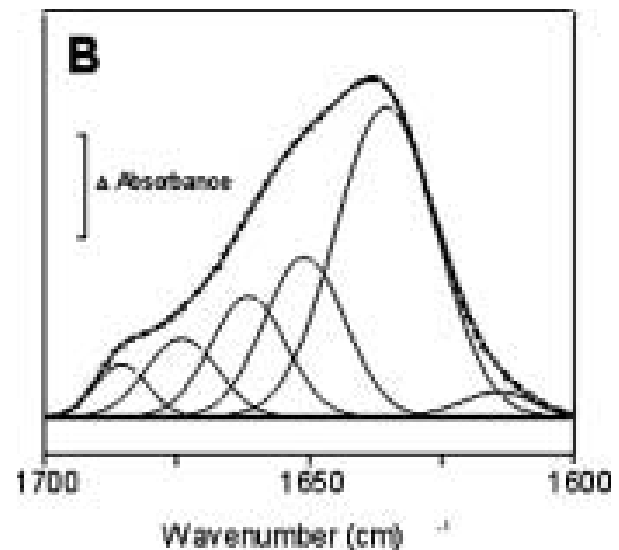

(B)

Fig. 5. Amide I band decomposition of the PKC $\varepsilon-\mathrm{C} 2$ domain in $\mathrm{H}_{2} \mathrm{O}(\mathrm{A})$ and $\mathrm{D}_{2} \mathrm{O}(\mathrm{B})$ at $25^{\circ} \mathrm{C}$. The position of the individual bands was obtained from the resolution-enhanced spectra represented in Fig. 2. The parameters corresponding to the component bands are reflected in Table 1. The dashed line represents the curve-fitted spectra. The increment of absorbance units $(\Delta)$ was 0.02 (A) and 0.1 (B). Reproduced with permission from Eur. J. Biochem. 268 (2001), 1107-1117. Copyright 2001 Blackwell Sci.

stability. As a control, we performed the same assay using $\mathrm{PKC} \alpha-\mathrm{C} 2$ and $100 \mathrm{~mol} \%$ phosphatidylcholine vesicles and no binding occurred. In this case, $\mathrm{PKC} \alpha$-C2 underwent thermal denaturation with a halfmidpoint temperature of $52-53^{\circ} \mathrm{C}$ (Fig. 4B), exactly the same temperature as in the absence of lipids (see Fig. 2A). Figure 4C shows the effect of thermal denaturation on the stability of the PKC-C2D246/248N mutant and as can be appreciated, a big increase in the stability of the protein occurred with lipid binding, confirming that the protein had bound to the lipid vesicles. These data suggest that the amino acidic residues involved in lipid binding are, at least in part, different from those involved in $\mathrm{Ca}^{2+}$ binding. Furthermore, lipid interaction led to a very high degree of protein structure stabilization and no change in secondary structure was detected even after heating to $70^{\circ} \mathrm{C}$.

Thermal denaturation studies of $\mathrm{PKC} \alpha$-C2-phosphatidic acid complexes reveal the very high stability of the protein compared with its free- $\mathrm{Ca}^{2+}$ and bound- $\mathrm{Ca}^{2+}$ states, indicating that thermal denaturation does not occur in these conditions, at least in the temperature range studied. This high stability is similar to that described for intrinsic membrane proteins $[50,65]$.

\subsection{Structure of the PKCE-C2 domain}

To study the structure of the $\mathrm{C} 2$ domain of $\mathrm{PKC} \varepsilon$ (PKC $\varepsilon-\mathrm{C} 2)$, a recombinant fusion protein was generated and purified as described in the Experimental procedures section. Protein structure was studied by analyzing the amide I region of the infrared spectrum both in $\mathrm{H}_{2} \mathrm{O}$ and in $\mathrm{D}_{2} \mathrm{O}$. Deconvolution of the spectrum obtained in $\mathrm{H}_{2} \mathrm{O}$-buffer showed four components and similar results were found after obtaining the second derivative spectrum. Five components were found when the $\mathrm{D}_{2} \mathrm{O}$ spectrum was submitted to deconvolution and second derivation. Quantitation was carried out by curve fitting to the original spectra (Fig. 5). The corresponding parameters, i.e. band position, percentage area, and bandwidth of each spectral component are displayed in Table 4. In the $\mathrm{H}_{2} \mathrm{O}$ spectrum, the main component was centered at $1639 \mathrm{~cm}^{-1}$ and amounted to $51 \%$. This wavelength can be attributed to $\beta$-sheet structure [31], the major structural component of $\mathrm{C} 2$ domains $[11,26]$. The component at $1658 \mathrm{~cm}^{-1}$, which amounted to $18 \%$, 
Table 4

FT-IR parameters of the amide I band components of PKC $\alpha$-C2 and PKC-C2D246/248N domains in the absence or presence of small unilamellar vesicles containing $100 \mathrm{~mol} \%$ phosphatidic acid, in $0.2 \mathrm{mM}$ EGTA $\mathrm{D}_{2} \mathrm{O}$ buffer at $25^{\circ} \mathrm{C}$. Reproduced with permission from Biochemistry 38 (1999), 9667-9675. Copyright 1999 Am. Chem. Soc.

\begin{tabular}{|c|c|c|c|c|c|c|c|c|}
\hline \multicolumn{3}{|c|}{$\mathrm{PKC} \alpha-\mathrm{C} 2$} & \multicolumn{6}{|c|}{$\mathrm{PKC} \alpha-\mathrm{C} 2 \mathrm{D} 246 / 248 \mathrm{~N}$} \\
\hline \multicolumn{3}{|c|}{ Phosphatidic acid } & \multicolumn{3}{|c|}{ No lipid } & \multicolumn{3}{|c|}{ Phosphatidic acid } \\
\hline $\begin{array}{l}\text { Position } \\
\left(\mathrm{cm}^{-1}\right)\end{array}$ & $\begin{array}{l}\text { Area } \\
(\%)\end{array}$ & $\begin{array}{l}\text { Width } \\
\left(\mathrm{cm}^{-1}\right)\end{array}$ & $\begin{array}{c}\text { Position } \\
\left(\mathrm{cm}^{-1}\right)\end{array}$ & $\begin{array}{l}\text { Area } \\
(\%)\end{array}$ & $\begin{array}{l}\text { Width } \\
\left(\mathrm{cm}^{-1}\right)\end{array}$ & $\begin{array}{c}\text { Position } \\
\left(\mathrm{cm}^{-1}\right)\end{array}$ & $\begin{array}{c}\text { Area } \\
(\%)\end{array}$ & $\begin{array}{l}\text { Width } \\
\left(\mathrm{cm}^{-1}\right)\end{array}$ \\
\hline 1693 & $<1$ & 11 & 1688 & 3 & 14 & 1693 & 1 & 14 \\
\hline 1677 & 8 & 19 & 1675 & 7 & 17 & 1677 & 10 & 22 \\
\hline 1663 & 17 & 19 & 1663 & 17 & 18 & 1662 & 23 & 22 \\
\hline 1653 & 14 & 17 & 1653 & 11 & 15 & 1652 & 12 & 16 \\
\hline 1644 & 21 & 20 & 1645 & 9 & 17 & 1643 & 18 & 19 \\
\hline 1631 & 39 & 28 & 1635 & 53 & 31 & 1631 & 35 & 29 \\
\hline
\end{tabular}

is usually assigned to $\alpha$-helix and/or unordered structures [28] but could also be assigned to large loops with dihedral angles similar to those of $\alpha$-helix [7,53,54,57]. The component at $1671 \mathrm{~cm}^{-1}$, amounting to $22 \%$, is assigned to $\beta$-turns $[20,21]$. Finally the band at $1689 \mathrm{~cm}^{-1}$, which can be assigned to the high frequency component of antiparallel $\beta$-sheet in the case of proteins in $\mathrm{H}_{2} \mathrm{O}$ solution [28] amounted to $9 \%$ of the total area.

When the protein was studied in $\mathrm{D}_{2} \mathrm{O}$, five components were basically detected both by deconvolution and derivation (Fig. 5). The band centered at $1636 \mathrm{~cm}^{-1}$ corresponds to a $\beta$-sheet structure and was the main component, representing $51 \%$ of the total area of the amide $\mathrm{I}^{\prime}$ band. The component located at $1651 \mathrm{~cm}^{-1}$ is usually assigned to $\alpha$ helix but, as in the case of the $1658 \mathrm{~cm}^{-1}$ component in the $\mathrm{H}_{2} \mathrm{O}$ buffer, it may also correspond to large loops or turns with dihedral angles similar to those of $\alpha$-helix [21, 31,51]. It is clear that the $1658 \mathrm{~cm}^{-1}$ component detected in the $\mathrm{H}_{2} \mathrm{O}$ buffer (Table 4) did not include unordered structures since they would have shifted to a lower frequency of about $1643 \mathrm{~cm}^{-1}$ in $\mathrm{D}_{2} \mathrm{O}$ buffer, but such a component was not detected [30]. The components located at $1662(15 \%)$ and $1686 \mathrm{~cm}^{-1}(4 \%)$ arise from $\beta$-turns and the $1674 \mathrm{~cm}^{-1}$ band (9\%) is usually assigned to antiparallel $\beta$-sheet structure [3, $32,33,52]$. Quantitation of the secondary structure and assignments of the $\mathrm{PKC} \varepsilon-\mathrm{C} 2$ domain in $\mathrm{D}_{2} \mathrm{O}$ are also summarized in Table 4 and will serve as a basis for the interpretation of temperature-dependent structural changes of the protein in $\mathrm{D}_{2} \mathrm{O}$ buffer. Thus, there was very good agreement between the quantitation made in $\mathrm{H}_{2} \mathrm{O}$ and in $\mathrm{D}_{2} \mathrm{O}$ solutions, with $60 \% \beta$-sheet being identified both in $\mathrm{H}_{2} \mathrm{O}$ (adding the 1639 and $1689 \mathrm{~cm}^{-1}$ components) and $\mathrm{D}_{2} \mathrm{O}$ (adding the 1636 and $1674 \mathrm{~cm}^{-1}$ components); $18 \% \alpha$-helix (or loops) in $\mathrm{H}_{2} \mathrm{O}$ and $21 \%$ in $\mathrm{D}_{2} \mathrm{O}$ and $22 \% \beta$-turns (adding the 1686 and $1662 \mathrm{~cm}^{-1}$ components) in $\mathrm{H}_{2} \mathrm{O}$ and $19 \%$ in $\mathrm{D}_{2} \mathrm{O}$.

A very good agreement was also reached between the secondary structure deduced from infrared spectroscopy and that concluded by means of X-ray diffraction from a crystal of this protein [55]. Table 2 shows that for $\beta$-pleated sheet the percentages found were $60 \%$ for infrared spectroscopy and $54 \%$ for X-ray diffraction (XRD), for $\alpha$-helix $21 \%$ (IR) and 20\% (XRD) and for $\beta$-turns $19 \%$ (IR) and $20 \%$ (XRD).

It is interesting that the $60 \%$ of $\beta$-sheet calculated for PKC $\varepsilon$ correlates also well with the percentages calculated by X-ray diffraction for C2 domains of the same topology, such as PLC $\delta(53 \%)$, cPLA2 (60\%) and $\mathrm{PKC} \delta$-C2 (53\%) domains $[17,36,44]$. Recent studies have shown the crystal structure of the PKC $\delta$ $\mathrm{C} 2$ domain, which belongs to the group of novel PKCs. However, the low sequence homology between $\mathrm{PKC} \varepsilon$ and $\mathrm{PKC} \delta \mathrm{C} 2$ domains suggests that further structural variations are expected to be found in this 


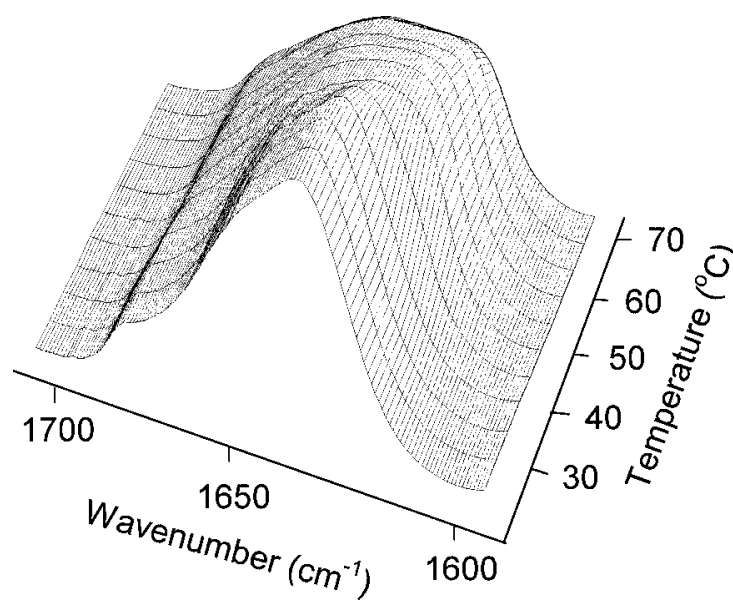

(A)

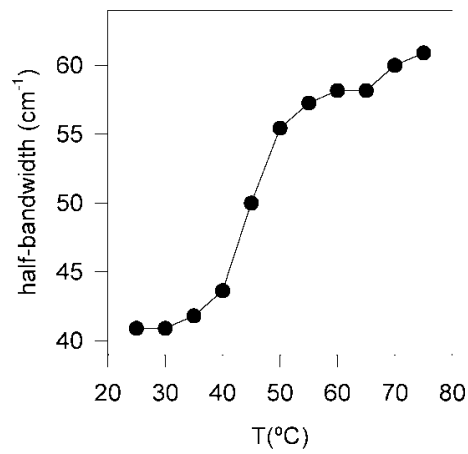

(B)

Fig. 6. (A) IR spectra of the $\mathrm{PKC} \varepsilon$-C 2 domain in $\mathrm{D}_{2} \mathrm{O}$ buffer containing $0.2 \mathrm{mM}$ EGTA in the amide $\mathrm{I}^{\prime}$ region $\left(1700-1600 \mathrm{~cm}^{-1}\right)$ as a function of temperature from 25 to $75^{\circ} \mathrm{C}$. The increment of absorbance units $(\Delta)$ was 0.1 . (B) Half-bandwidth of the amide $\mathrm{I}^{\prime}$ region of the IR spectra in $\mathrm{cm}^{-1}$ as a function of temperature, for the $\mathrm{PKC} \varepsilon-\mathrm{C} 2$ domain. Reproduced with permission from Eur. J. Biochem. 268 (2001), 1107-1117. Copyright 2001 Blackwell Sci.

group [17]. For example, there is an extended sequence in the CBR1-like loop of PKC $\varepsilon$ that could adopt a large loop conformation similar to that described in the CBR1 of PLC $\delta 1$, PTEN or PI3K $[13,34,36]$. Another possibility is that this part of the domain adopts a helical conformation similar to that of cPLA2CBR1, which is involved in membrane interaction [44]. Thus, one of those structures may be the origin of the extra helical component found in the IR spectrum of PKC $\varepsilon-C 2$ domain at 1651 and $1658 \mathrm{~cm}^{-1}$, in $\mathrm{D}_{2} \mathrm{O}$ and $\mathrm{H}_{2} \mathrm{O}$, respectively, since both $\alpha$-helix and large loops appear together at those frequencies [7, $28,53,54]$.

\subsection{Study of the thermal stability of the PKCE-C2 domain by IR}

Protein thermal denaturation can be followed using infrared spectroscopy by studying the temperatureinduced changes produced in the amide $\mathrm{I}^{\prime}$ band. Protein thermal denaturation profiles are sensitive tools which reveal small conformational differences that are not always apparent from the individual infrared spectra.

The band decomposition procedure used in this work enabled us to analyse the thermally induced changes in protein structure in detail and the thermal behaviour of the individual structural elements. In general, large changes $\left(\geqslant 10 \mathrm{~cm}^{-1}\right)$ in band position seem to indicate variations in the secondary structure, whereas smaller shifts $\left(\leqslant 6 \mathrm{~cm}^{-1}\right)$ reflect local changes in a given conformation [31]. Figure 6A shows the pattern of $\mathrm{PKC} \varepsilon-\mathrm{C} 2$ domain upon heating, with the spectra basically revealing a typical broadening of the overall amide $\mathrm{I}^{\prime}$ contour $[24,46,62]$. Figure 6B depicts a plot of half-bandwidth versus temperature, which permitted the $T_{\mathrm{m}}$ transition temperature to be calculated $\left(45^{\circ} \mathrm{C}\right.$ approximately).

In order to study the thermal denaturation characteristics of this domain we have decomposed the different spectra into their constituents by curve-fitting. The number of components and positions were determined by previous deconvolution and derivation similarly to the spectra obtained at $25^{\circ} \mathrm{C}$. The most significant changes compared with the spectrum recorded at $25^{\circ} \mathrm{C}$ (Fig. 5B) are the appearance of two new components at 1645 and $1622 \mathrm{~cm}^{-1}$ at $45^{\circ} \mathrm{C}$, which gradually increased with increasing 


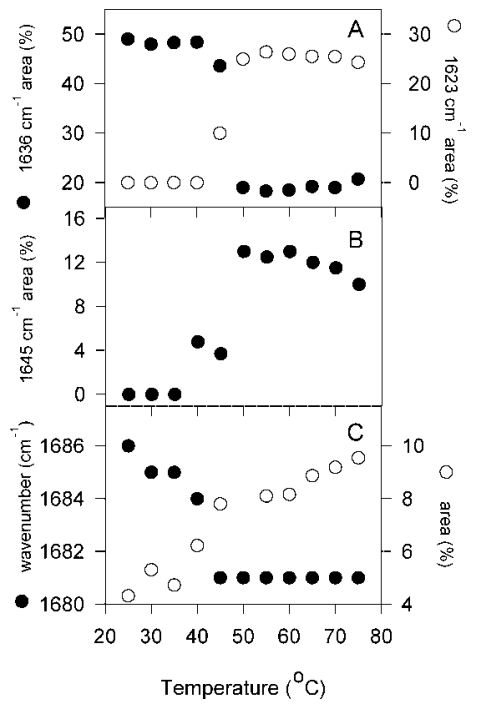

Fig. 7. Thermal profiles of the amide $\mathrm{I}^{\prime}$ components. (A) Percentage of band area detected at $1636 \mathrm{~cm}^{-1}(\beta$-sheet) (•) and at $1623 \mathrm{~cm}^{-1}$ (aggregation) (o) versus temperature. (B) Percentage of band area detected at $1645 \mathrm{~cm}^{-1}$ (unordered) versus temperature. (C) Band position starting at $1680 \mathrm{~cm}^{-1}$ at $25^{\circ} \mathrm{C}(\bullet)$ and percentage of band area of the same component (o) versus temperature. Reproduced with permission from Eur. J. Biochem. 268 (2001), 1107-1117. Copyright 2001 Blackwell Sci.

temperatures up to $60-80^{\circ} \mathrm{C}$. The former can be attributed to an unordered structure [28] and the second to certain structures that arise upon thermal denaturation, such as extended chains not forming $\beta$-sheet ( $\beta$-strands), irreversible aggregation or denaturated conformation $[2,9,31,58]$.

An analysis of the peak positions, and the percentile areas of each component obtained by curvefitting provided an idea of the secondary structural changes that occur during the thermal process. For example, the area of the component appearing at $1636 \mathrm{~cm}^{-1}$, which has been attributed to $\beta$-sheet, abruptly decreased at $50^{\circ} \mathrm{C}$ from 49 to $19 \%$ (Fig. 7A). Furthermore, this decrease was correlated by an increasing in the percentage of the area of the $1622 \mathrm{~cm}^{-1}$ band from 0 to $25 \%$ at $50^{\circ} \mathrm{C}$, suggesting that the emergence of the last component was a consequence of the process that induced the disappearance of the $1636 \mathrm{~cm}^{-1}$ component. Figure 7B shows the changes which occurred, with another new component appearing at $1644 \mathrm{~cm}^{-1}$ (assigned to unordered structure) and representing a maximum of $10-12 \%$ at the highest temperatures. This band seems to arise from the 1651 and $1636 \mathrm{~cm}^{-1}$ components that may be partially denaturated during the heating. A further significant change (Fig. 7C) concerned the component at $1686 \mathrm{~cm}^{-1}$, which shifted to $1681 \mathrm{~cm}^{-1}$ at the same time that the percentage of its area increased from $4 \%$ at $25^{\circ} \mathrm{C}$ to $10 \%$ at $75^{\circ} \mathrm{C}$ [23]. These data suggest that there is only a small reorganization in the initial conformation of the $\beta$-turns, for example, the component at $1651 \mathrm{~cm}^{-1}$ slightly shifted to $1653 \mathrm{~cm}^{-1}$ at $40^{\circ} \mathrm{C}$. Furthermore, the percentage of the area decreased from $21 \%$ at $25^{\circ} \mathrm{C}$ to $14 \%$ at $40^{\circ} \mathrm{C}$ and stayed constant during denaturation, indicating that this component, which is attributed to $\alpha$-helix or large loops, is very stable during the heating process.

\subsection{Effect of lipid binding on the structure of $P K C \varepsilon-C 2$ domain and its thermal denaturation pattern}

IR was used to determine the effect of phosphatidic acid vesicles binding on the secondary structure of the $\mathrm{PKC} \varepsilon-\mathrm{C} 2$ domain. The spectrum was obtained and curve fitting was carried out for the $\mathrm{PKC} \varepsilon$ $\mathrm{C} 2$ domain bound to vesicles containing $100 \mathrm{~mol} \%$ of phosphatidic acid in $\mathrm{D}_{2} \mathrm{O}$ at $25^{\circ} \mathrm{C}$ in the 1780 
Table 5

Peak positions and assignment of the amide I and amide $\mathrm{I}^{\prime}$ bands of $\mathrm{PKC} \varepsilon-\mathrm{C} 2$ domain. Reproduced with permission from Eur. J. Biochem. 268 (2001), 1107-1117. Copyright 2001 Blackwell Sci.

\begin{tabular}{|c|c|c|c|c|c|c|c|}
\hline \multicolumn{4}{|c|}{$\mathrm{H}_{2} \mathrm{O}$} & \multicolumn{4}{|c|}{$\mathrm{D}_{2} \mathrm{O}$} \\
\hline $\begin{array}{l}\text { Position } \\
\left(\mathrm{cm}^{-1}\right)\end{array}$ & $\begin{array}{c}\text { Area } \\
(\%)\end{array}$ & $\begin{array}{l}\text { Width } \\
\left(\mathrm{cm}^{-1}\right)\end{array}$ & Assignment & $\begin{array}{c}\text { Position } \\
\left(\mathrm{cm}^{-1}\right)\end{array}$ & $\begin{array}{l}\text { Area } \\
(\%)\end{array}$ & $\begin{array}{l}\text { Width } \\
\left(\mathrm{cm}^{-1}\right)\end{array}$ & Assignment \\
\hline 1689 & 9 & 19 & Antiparallel $\beta$-sheet & 1686 & 4 & 14 & $\beta$-turns \\
\hline 1671 & 22 & 27 & $\beta$-turns & 1674 & 9 & 19 & Antiparallel $\beta$-sheet \\
\hline \multirow[t]{2}{*}{1658} & 18 & 23 & $\begin{array}{l}\alpha \text {-helix, unordered } \\
\text { structure or large } \\
\text { loops }\end{array}$ & 1662 & 15 & 20 & $\beta$-turns \\
\hline & & & & 1651 & 21 & 21 & $\begin{array}{l}\alpha \text {-helix, large } \\
\text { loops or turns with } \\
\text { dihedral angles } \\
\text { similar to } \alpha \text {-helix }\end{array}$ \\
\hline 1639 & 51 & 31 & $\beta$-sheet & 1636 & 51 & 27 & $\beta$-sheet \\
\hline
\end{tabular}

Table 6

Peak positions of the amide I' band of PKC $\varepsilon$-C 2 domain bound to phosphatidic acid at 25 and $75^{\circ} \mathrm{C}$. Reproduced with permission from Eur. J. Biochem. 268 (2001), 1107-1117. Copyright 2001 Blackwell Sci.

\begin{tabular}{ccccccc}
\hline & $25^{\circ} \mathrm{C}$ & & & $35^{\circ} \mathrm{C}$ \\
\cline { 1 - 1 } \cline { 5 - 6 } $\begin{array}{c}\text { Position } \\
\left(\mathrm{cm}^{-1}\right)\end{array}$ & $\begin{array}{c}\text { Area } \\
(\%)\end{array}$ & $\begin{array}{c}\text { Width } \\
\left(\mathrm{cm}^{-1}\right)\end{array}$ & & $\begin{array}{c}\text { Position } \\
\left(\mathrm{cm}^{-1}\right)\end{array}$ & $\begin{array}{c}\text { Area } \\
(\%)\end{array}$ & $\begin{array}{c}\text { Width } \\
\left(\mathrm{cm}^{-1}\right)\end{array}$ \\
\hline 1686 & 5 & 21 & & 1686 & 8 & 30 \\
1674 & 6 & 19 & & 1673 & 10 & 21 \\
1662 & 13 & 23 & & 1662 & 15 & 21 \\
1651 & 21 & 26 & & 1650 & 19 & 24 \\
1635 & 53 & 32 & & 1635 & 48 & 36 \\
\hline
\end{tabular}

$1600 \mathrm{~cm}^{-1}$ region. The curve fitting data point to a secondary structure very similar to that obtained in the absence of lipids [23] which suggests that no differences or changes in the secondary structure occur when lipid binding takes place. It is interesting to note that these results are different from those observed for the PKC $\alpha$-C2 domain, which showed an increase in the component representing unordered and open loop structures upon lipid binding [24].

The effect of heating on the secondary structure of $\mathrm{PKC} \varepsilon-\mathrm{C} 2$ in the presence of phosphatidic acid was also followed by IR. The heating profile showed few changes in the temperature range that was studied. To better characterize these changes, the spectrum obtained at $75^{\circ} \mathrm{C}$ was analyzed by curve fitting (Table 6), which revealed that the component at $1635 \mathrm{~cm}^{-1}$ decreased to $48 \%$ of the total area (from $53 \%$ at $25^{\circ} \mathrm{C}$ ). Nevertheless, if we consider the contribution of the $1674 \mathrm{~cm}^{-1}$ band, the total percentage of the $\beta$-sheet components was $58 \%$, which implies that no significant changes took place with this heating process, since it amounted to $60 \%$ at $25^{\circ} \mathrm{C}$. The other components were very similar to those obtained at $25^{\circ} \mathrm{C}$ (Table 5), suggesting that in the presence of phosphatidic acid, the heating process carried out here produced only slight modifications in the secondary structure under our experimental conditions. 


\subsection{Comparison of $C 2$ from $P K C \alpha$ and $C 2$ from $P K C \varepsilon$}

Some significant differences were observed between both $\mathrm{C} 2$ domains, knowing that whereas the $\mathrm{C} 2$ domain from PKC $\alpha$ has a type I topology, the $\mathrm{C} 2$ from PKC $\varepsilon$ has a type II topology. It is interesting to note that in spite of sharing a core $\beta$-sheet with many other $\mathrm{C} 2$ domains, including the $\mathrm{PKC} \alpha-\mathrm{C} 2$ domain, IR detected significant differences between this last domain and the PKC $\varepsilon-\mathrm{C} 2$ [23,24]. For example, the component at $1644 \mathrm{~cm}^{-1}$ assigned to open loops and unordered structure in the $\mathrm{PKC} \alpha-\mathrm{C} 2$ cannot be found in the PKC $\varepsilon-\mathrm{C} 2$ domain. Moreover, the band at $1651 \mathrm{~cm}^{-1}$ which is attributed to $\alpha$-helix or large loops, is significantly greater in the $\mathrm{PKC} \varepsilon-\mathrm{C} 2$ in $\mathrm{D}_{2} \mathrm{O}$ solution (21\%) than in $\mathrm{PKC} \alpha-\mathrm{C} 2(12 \%)$.

The effect of lipid binding was also different, so that it induced a well detectable change in $\mathrm{C} 2$ from $\mathrm{PKC} \alpha$ but very little change was appreciated for the $\mathrm{C} 2$ of $\mathrm{PKC} \varepsilon$.

With respect to thermal stability, it has been shown that in $\mathrm{PKC} \alpha-\mathrm{C} 2$ domain, the unordered structures and those components characteristic of thermal denaturation $\left(1646,1625\right.$ and $\left.1680 \mathrm{~cm}^{-1}\right)$ increase substantially at $75^{\circ} \mathrm{C}$, a finding which correlates well with the decrease observed in the percentage of the $\alpha$-helical and $\beta$-sheet components [24]. On the other hand, the $\mathrm{PKC} \varepsilon-\mathrm{C} 2$ domain retains the $1651 \mathrm{~cm}^{-1}$ component and part of the $\beta$-sheet structure after heating. These results demonstrate that the $\mathrm{PKC} \varepsilon-\mathrm{C} 2$ domain is more stable than the PKC $\alpha-C 2$ domain in the absence of $\mathrm{Ca}^{2+}$. These results support the idea that one of $\mathrm{Ca}^{2+}$ functions is to stabilize the domain before lipid binding and thus, in the cases where the function of the $\mathrm{C} 2$ domain is independent of calcium this role is played by the protein itself. Furthermore, many studies of the C2 domains of topology II, such as cPLA2, have demonstrated that CBR1 and CBR3 contain hydrophobic residues that are very important for membrane binding [35,43]. The homologous residues of $\mathrm{PKC} \varepsilon-\mathrm{C} 2$ domain, which contribute to $\mathrm{CBR} 1$ and $\mathrm{CBR} 3$, could be potential candidates for the absorbance seen at this particular wavelength $\left(1651 \mathrm{~cm}^{-1}\right)$. These results suggest that the $\mathrm{PKC} \varepsilon-\mathrm{C} 2$ domain possesses a more ordered secondary structure than other $\mathrm{C} 2$ domains, which may be due to the connecting loops since the core $\beta$-sheet is similar in all $\mathrm{C} 2$ domains.

The C2 domains of novel PKCs constitute a special case since they have been classified as topology II although their membrane binding capacity depends on acidic phospholipids in a $\mathrm{Ca}^{2+}$-independent way [15]. It has been demonstrated recently that $\mathrm{PKC} \varepsilon$, due to the lack of $\mathrm{Ca}^{2+}$ binding, interacts with low specificity with PS and DAG, which implies the presence of other physiological activators for this form [39]. For example, it is well established that PLD activation induces an increase of phosphatidic acid in biological membranes [27] and this could be a way of activating PKC $\varepsilon$. As it was demonstrated previously [23] the $\mathrm{PKC} \varepsilon-\mathrm{C} 2$ domain has an important affinity for phosphatidic acid vesicles although the secondary structure of the domain did not change upon lipid binding, in contrast with PKC $\alpha-\mathrm{C} 2$ domain that underwent significant changes ([23] and this work). These results correlate well with the need for the PKC $\alpha$ to penetrate the membrane to be fully activated, the result of which could be the structural reorganization seen by IR. Experiments on phospholipid monolayer penetration, on the other hand, have revealed that $\mathrm{PKC} \varepsilon$ penetrates the membrane to a lesser extent than $\mathrm{PKC} \alpha$. This might result in no secondary structural reorganization upon lipid binding, although some reorganization at the tertiary level cannot be discarded [39].

\section{Acknowledgements}

We are very grateful to Dr. Ono and Dr. Nishizuka (Kobe University, Japan) for the kind gift of the cDNA codifying PKC $\varepsilon$. This work was supported by Grant PB98-0389 from Dirección General de Enseñanza Superior e Investigación Científica (Spain) and by Grant PI-35/00789/FS/01 from Fundación Séneca (Murcia). 


\section{References}

[1] A. Dessen, J. Tang, H. Schmidt, M. Stahl, J.D. Clark, J. Seehra and W.S. Somers, Crystal structure of human cytosolic phospholipase A2 reveals a novel topology and catalytic mechanism, Cell 97 (1999), 349-360.

[2] A. Martinez, J. Haavik, T. Flatmark, J.L.R. Arrondo and A. Muga, Conformational properties and stability of tyrosine hydroxylase studied by infrared spectroscopy. Effect of iron/catecholamine binding and phosphorylation, J. Biol. Chem. 271 (1996), 19737-19742.

[3] A. Muga, J.L.R. Arrondo, T. Bellon, J. Sancho and C. Bernabeu, Structural and functional studies on the interaction of sodium dodecyl sulfate with beta-galactosidase, Arch. Biochem. Biophys. 300 (1993), 451-455.

[4] A. Newton and J.E. Johnson, Protein kinase C: a paradigm for regulation of protein function by two membrane-targeting modules, Biochim. Biophys. Acta 1376 (1998), 155-172.

[5] A.S. Edwards and A.C. Newton, Regulation of protein kinase C $\beta$ II by its C2 domain, Biochemistry 36 (1997), 15 61515623.

[6] B.A. Davletov and T.C. Südhof, A single C2 domain from synaptotagmin I is sufficient for high affinity $\mathrm{Ca}^{2+} / \mathrm{phospholipid}^{2}$ binding, J. Biol. Chem. 268 (1993), 26386-26390.

[7] C.L. Wilder, A.D. Friedrich, R.O. Potts, G.O. Daumy and M.L. Francoeur, Secondary structural analysis of two recombinant murine proteins, interleukins 1 alpha and 1 beta: is infrared spectroscopy sufficient to assign structure?, Biochemistry 31 (1992), 27-31.

[8] D. Chapman, M. Jackson and P.I. Haris, Investigation of membrane protein structure using Fourier transform infrared spectroscopy, Biochem. Soc. Trans. 17 (1989), 617-619.

[9] D. Naumann, C. Schultz, U. Görne-Tschelnokow and F. Hucho, Secondary structure and temperature behavior of the acetylcholine receptor by Fourier transform infrared spectroscopy, Biochemistry 32 (1993), 3162-3169.

[10] D.M. Byler and H. Susi, Examination of the secondary structure of proteins by deconvolved FTIR spectra, Biopolymers 25 (1986), 469-487.

[11] E.A. Nalefski and J.J. Falke, The C2 domain calcium-binding motif: structural and functional diversity, Protein Science 5 (1996), 2375-2390.

[12] E.A. Nalefski, M.M. Slazas and J.J. Falke, Calcium signaling cycle of a membrane-docking C2 domain, Biochemistry 36 (1997), 12 011-12018

[13] E.H. Walker, O. Perisic, C. Rled, L. Stephens and R.L. Williams, Structural insights into phosphoinositide 3-kinase catalysis and signalling, Nature $\mathbf{4 0 2}$ (1999), 313-320.

[14] H. Fabian, D. Naumann, R. Misselwitz, O. Ristau, D. Gerlach and H. Welfle, Secondary structure of streptokinase in aqueous solution: a Fourier transform infrared spectroscopic study, Biochemistry 31 (1992), 6532-6538.

[15] H. Koide, K. Ogita, U. Kikkawa and Y. Nishizuka, Isolation and characterization of the epsilon subspecies of protein kinase C from rat brain, Proc. Natl. Acad. Sci. USA 89 (1992), 1149-1153.

[16] H. Mellor and P.J. Parker, The extended protein kinase C superfamily, Biochem. J. 332 (1998), 281-292.

[17] H. Pappa, J. Murray-Rust, L.V. Dekker, P.J. Parker and N.Q. McDonald, Crystal structure of the C2 domain from protein kinase C $\delta$, Structure 6 (1998), 885-894.

[18] H. Susi, Infrared spectroscopy-conformation, Methods Enzymol. 26 (1972), 455-472.

[19] H. Zhang, Y. Ishikawa, Y. Yamamoto and R. Carpentier, Secondary structure of streptokinase in aqueous solution: a Fourier transform infrared spectroscopic study, FEBS Letters 426 (1998), 347-351.

[20] J. Bandekar and S. Krimm, Vibrational analysis of peptides, polypeptides, and proteins. VI. Assignment of beta-turn modes in insulin and other proteins, Biopolymers 19 (1980), 31-36.

[21] J. Bandekar, Amide modes and protein conformation, Biochim. Biophys. Acta 1120 (1992), 123-143.

[22] J. Cladera, H.L. Galisteo, M. Sabes, P.L. Mateo and E. Padros, The role of retinal in the thermal stability of the purple membrane, Eur. J. Biochem. 207 (1992), 581-585.

[23] J. García-García, J.C. Gómez-Fernández and S. Corbalán-García, Structural characterization of the C2 domain of novel protein kinase C $\varepsilon$, Eur. J. Biochem. 268 (2001), 1107-1117.

[24] J. García-García, S. Corbalán-García and J.C. Gómez-Fernández, Effect of calcium and phosphatidic acid binding on the C2 domain of PKC $\alpha$ as studied by Fourier transform infrared spectroscopy, Biochemistry 38 (1999), 9667-9675.

[25] J. Hofmann, The potential for isoenzyme-selective modulation of protein kinase C, FASEB J. 11 (1997), 649-669.

[26] J. Rizo and T.C. Südhof, C2-domains, structure and function of a universal $\mathrm{Ca}^{2+}$-binding domain, J. Biol. Chem. 273 (1998), $15879-15882$.

[27] J.H. Exton, New developments in phospholipase D, J. Biol. Chem. 272 (1997), 15 579-15 582.

[28] J.L.R. Arrondo and F.M. Goñi, Structure and dynamics of membrane proteins as studied by infrared spectroscopy, Prog. Biophys. Mol. Biol. 72 (1999), 367-405.

[29] J.L.R. Arrondo, A. Muga, J. Castresana, C. Bernabeu and F.M. Goñi, An infrared spectroscopic study of $\beta$-galactosidase structure in aqueous solutions, FEBS Letters 252 (1989), 118-120. 
[30] J.L.R. Arrondo, I. Etxabe, U. Dornberger and F.M. Goñi, Probing protein conformation by infrared spectroscopy, Biochem. Soc. Trans. 22 (1994), 380S.

[31] J.L.R. Arrondo, J. Castresana, J.M. Valpuesta and F.M. Goñi, Structure and thermal denaturation of crystalline and noncrystalline cytochrome oxidase as studied by infrared spectroscopy, Biochemistry 33 (1994), 11 650-11 655.

[32] J.L.R. Arrondo, A. Muga, J. Castresana and F.M. Goñi, Quantitative studies of the structure of proteins in solution by Fourier-transform infrared spectroscopy, Prog. Biophys. Mol. Biol. 59 (1993), 23-56.

[33] J.M. Olinger, D.M. Hill, R.J. Jakobsen and R.S. Brody, Fourier transform infrared studies of ribonuclease in $\mathrm{H}_{2} \mathrm{O}$ and ${ }^{2} \mathrm{H}_{2} \mathrm{O}$ solutions, Biochim. Biophys. Acta 869 (1986), 89-98.

[34] J.O. Lee, H. Yang, M.-M. Georgescu, A.D. Cristofano, T. Maehama, Y. Shi, J.E. Dixon, P. Pandolfi and N.P. Pavletich, Crystal structure of the PTEN tumor suppressor: implications for its phosphoinositide phosphatase activity and membrane association, Cell 99 (1999), 323-334.

[35] L. Bittova, M. Sumandea and W. Cho, A structure-function study of the C2 domain of cytosolic phospholipase A2, J. Biol. Chem. 274 (1999), 9665-9672.

[36] L.O. Essen, O. Perisic, R. Cheung, M. Katan and R.L. Williams, Crystal structure of a mammalian phosphoinositidespecific phospholipase C $\delta$, Nature 380 (1996), 595-602.

[37] M. Gonzalez, L.A. Bagatolli, I. Echabe, J.L.R. Arrondo, C.E. Argaraña, C.R. Cantor and G.D. Fidelio, J. Biol. Chem. 272 (1997), 11 288-11294.

[38] M. Jackson, P.I. Haris and D. Chapman, Fourier transform infrared spectroscopic studies of $\mathrm{Ca}^{2+}$-binding proteins, Biochemistry 30 (1991), 9681-9686.

[39] M. Medkova and W. Cho, Differential membrane-binding and activation mechanisms of protein kinase $\mathrm{C} \alpha$ and $\varepsilon, B i o-$ chemistry 37 (1998), 4892-4900.

[40] M. Medkova and W. Cho, Interplay of $\mathrm{C} 1$ and $\mathrm{C} 2$ domains of protein kinase $\mathrm{C}$-alpha in its membrane binding and activation, J. Biol. Chem. 274 (1999), 19852-19861.

[41] M. Medkova and W. Cho, Mutagenesis of the C2 domain of protein kinase C $\alpha$, J. Biol. Chem. 273 (1998), $17544-17552$.

[42] N. Verdaguer, S. Corbalán-García, W.F. Ochoa, I. Fita and J.C. Gómez-Fernández, $\mathrm{Ca}^{2+}$ bridges the $\mathrm{C} 2$ membrane-binding domain of protein kinase $\mathrm{C} \alpha$ directly to phosphatidylserine, EMBO J. 18 (1999), 6329-6338.

[43] O. Perisic, H.F. Paterson, G. Mosedale, S. Lara-Gonzalez and R.L. Williams, Mapping the phospholipid-binding surface and translocation determinants of the C2 domain from cytosolic phospholipase A2, J. Biol. Chem. 274 (1999), 1497914987.

[44] O. Perisic, S. Fong, D.E. Lynch, M. Bycroft and R.L. Williams, Crystal structure of a calcium-phospholipid binding domain from cytosolic phospholipase A2, J. Biol. Chem. 273 (1998), 1596-1604.

[45] P.J. Plant, H. Yeger, O. Staub, P. Howard and D. Rotin, The C2 domain of the ubiquitin protein ligase Nedd4 mediates $\mathrm{Ca}^{2+}$-dependent plasma membrane localization, J. Biol. Chem. 272 (1997), 32 329-32 336

[46] R. Chehin, Y. Iloro, M.J. Marcos, E. Villar, V.L. Shnyrov and J.L.R. Arrondo, Thermal and pH-induced conformational changes of a beta-sheet protein monitored by infrared spectroscopy, Biochemistry 38 (1999), 1525-1530.

[47] R.B. Sutton and S.R. Sprang, Structure of the protein kinase $\mathrm{C} \beta$ phospholipid-binding C2 domain complexed with $\mathrm{Ca}^{2+}$, Structure 6 (1998), 1395-1405.

[48] R.B. Sutton, B.A. Davletov, A.M. Berghuis, T.C. Südhof and S.R. Sprang, Structure of the first C2 domain of synaptotagmin I: a novel $\mathrm{Ca}^{2+}$ /phospholipid-binding fold, Cell 80 (1995), 929-938.

[49] S. Corbalán-García, J.A. Rodríguez-Alfaro and J.C. Gómez-Fernández, Determination of the calcium-binding sites of the $\mathrm{C} 2$ domain of protein kinase $\mathrm{C} \alpha$ that are critical for its translocation to the plasma membrane, Biochem. J. 337 (1999), $513-521$.

[50] S. Corbalán-García, J.A. Teruel, J. Villalaín and J.C. Gómez-Fernández, Extensive proteolytic digestion of the $\left(\mathrm{Ca}^{2+}\right.$ $\mathrm{Mg}^{2+}$ )-ATPase from sarcoplasmic reticulum leads to a highly hydrophobic proteinaceous residue with a mainly alphahelical structure, Biochemistry 33 (1994), 8247-8254.

[51] S. Krim and J. Bandekar, Vibrational spectroscopy and conformation of peptides, polypeptides, and proteins, Adv. Protein Chem. 38 (1986), 181-364.

[52] S.A. Tatuliam, D.M. Cortes and E. Perozo, Structural dynamics of the Streptomyces lividans $\mathrm{K}^{+}$channel (SKC1): secondary structure characterization from FTIR spectroscopy, FEBS Lett. 423 (1998), 205-212.

[53] S.J. Prestelski, D.M. Byler and M.N. Liebman, Comparison of various molecular forms of bovine trypsin: correlation of infrared spectra with X-ray crystal structures, Biochemistry 30 (1991), 133-143.

[54] S.L. Prestrelski, T. Arakawa, W.C. Kenney and D.M. Byler, The secondary structure of two recombinant human growth factors, platelet-derived growth factor and basic fibroblast growth factor, as determined by Fourier-transform infrared spectroscopy, Archiv. Biochem. Biophys. 285 (1991), 111-115.

[55] W.F. Ochoa, J. García-García, I. Fita, S. Corbalán-García, N. Verdaguer and J.C. Gómez-Fernández, Structure of the C2 domain from novel protein kinase $\mathrm{C} \varepsilon$. A membrane binding model for $\mathrm{Ca}^{2+}$-independent $\mathrm{C} 2$ domains, J. Mol. Biol. 311 (2001), 837-849.

[56] W.F. Ochoa, S. Corbalán-García, R. Eritja, J.A. Rodríguez-Alfaro, J.C. Gómez-Fernández, I. Fita and N. Verdaguer, Ad- 
ditional binding sites for anionic phospholipids and calcium ions in the crystal structures of complexes of the $\mathrm{C} 2$ domain of protein kinase $\mathrm{C} \alpha$, J. Mol. Biol. (2002), in press.

[57] W.K. Surewicz, H.H. Mantsch and D. Chapman, Determination of protein secondary structure by Fourier transform infrared spectroscopy: a critical assessment, Biochemistry 32 (1993), 389-394.

[58] W.K. Surewicz, J.J. Leddy and H.H. Mantsch, Structure, stability, and receptor interaction of cholera toxin as studied by Fourier-transform infrared spectroscopy, Biochemistry 29 (1990), 8106-8111

[59] W.K. Surewicz, T.M. Stepanik, A.G. Szabo and H.H. Mantsch, Lipid-induced changes in the secondary structure of snake venom cardiotoxins, J. Biol. Chem. 263 (1988), 786-790.

[60] W. Orr, L.M. Keranen and A.C. Newton, Reversible exposure of the pseudosubstrate domain of protein kinase C by phosphatidylserine and diacylglycerol, J. Biol. Chem. 267 (1992), 15 263-15 266.

[61] J.W. Orr and A.C. Newton, Interaction of protein kinase C with phosphatidylserine: 2. Specificity and regulation, Biochemistry 31 (1992), 4667-4673.

[62] X. Hang, G. Li, G. Li and K. Lin, FTIR study of the thermal denaturation of alpha-actinin in its lipid-free and dioleoylphosphatidylglycerol-bound states and the central and N-terminal domains of alpha-actinin in $\mathrm{D}_{2} \mathrm{O}$, Biochemistry 37 (1998), 10 730-10 737.

[63] X. Shao, B.A. Davletov, R.B. Sutton, T.C. Südhof and J. Rizo, Bipartite $\mathrm{Ca}^{2+}$ binding motif in C2 domains of synaptotagmin and PKC, Science 273 (1996), 248-251.

[64] X. Shao, Y. Fernandez, T.C. Südhof and J. Rizo, Solution structures of the $\mathrm{Ca}^{2+}$-free and $\mathrm{Ca}^{2+}$-bound C2A domain of synaptotagmin I: does $\mathrm{Ca}^{2+}$ induce a conformational change?, Biochemistry 37 (1998), 16 106-16115.

[65] Y. Echabe, U. Dornberger, A. Prado, F.M. Goñi and J.L.R. Arrondo, Topology of sarcoplasmic reticulum Ca ${ }^{2+}-$ ATPase: $^{2}$ an infrared study of thermal denaturation and limited proteolysis, Protein Sci. 7 (1998), 1172-1179.

[66] Y. Nishizuka, Protein kinase C and lipid signaling for sustained cellular responses, FASEB J. 9 (1995), 484-496. 


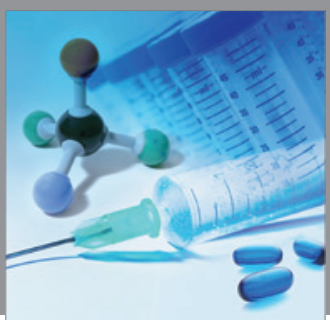

International Journal of

Medicinal Chemistry

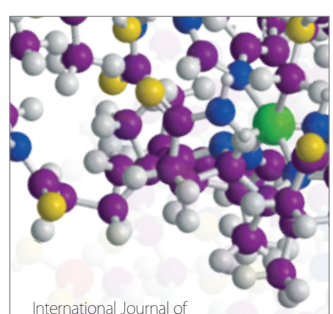

Carbohydrate Chemistry

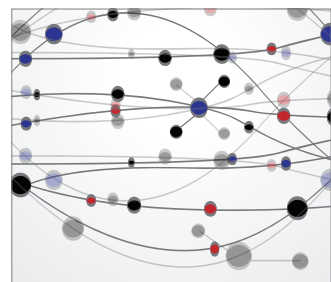

The Scientific World Journal
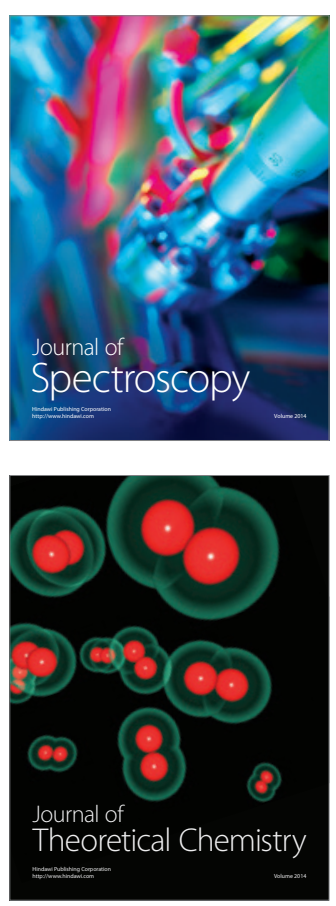
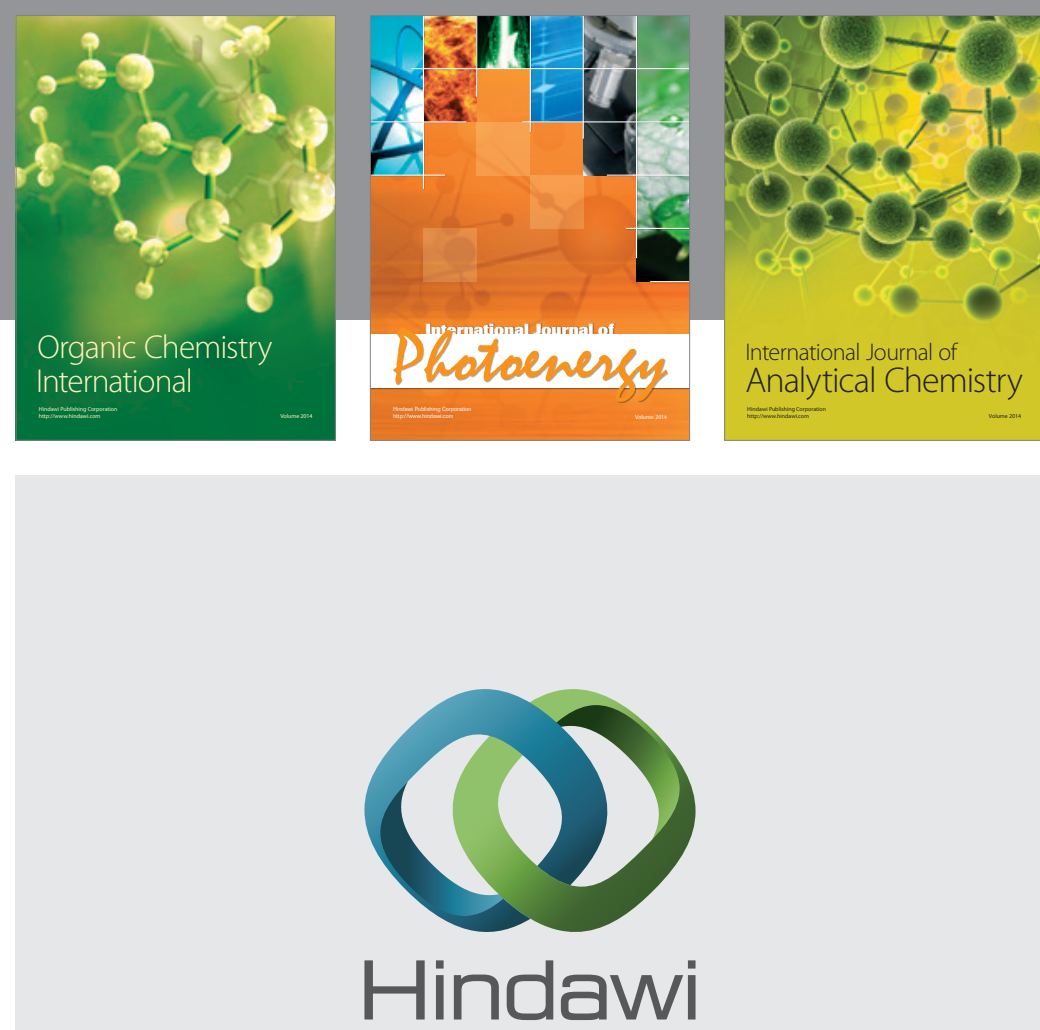

Submit your manuscripts at

http://www.hindawi.com
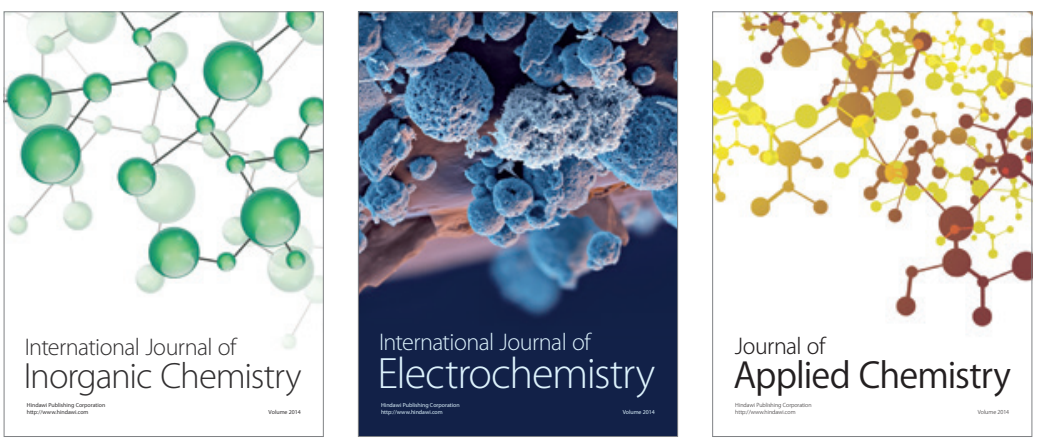

Journal of

Applied Chemistry
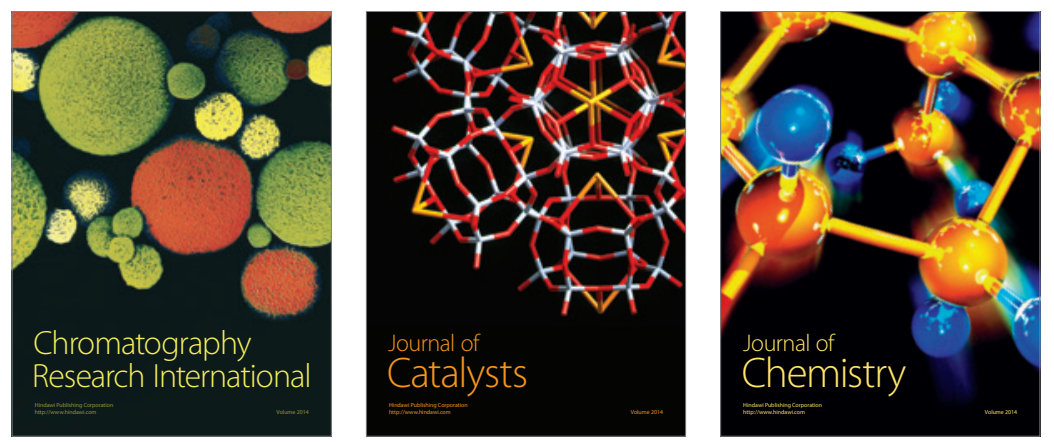
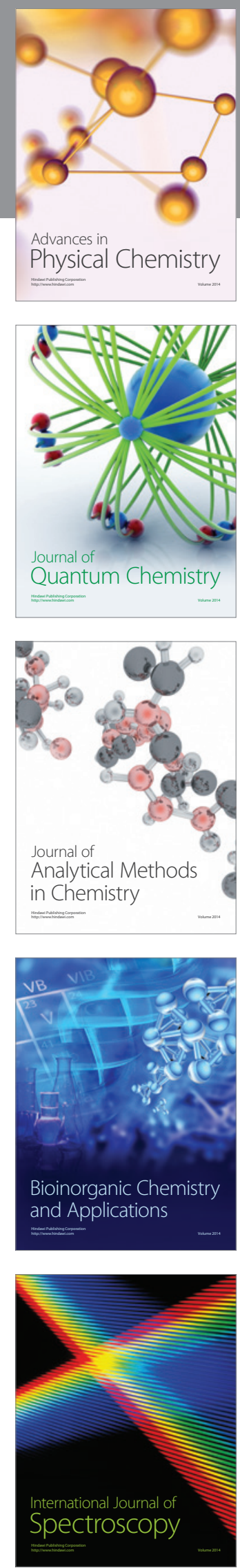